Quaternary International

Available online 12 January 2017

DOI: $10.1016 /$ j.quaint.2016.11.034

\title{
Hunter-gatherer specialization in the late Neolithic of southern Vietnam - The case of Rach Nui
}

Cristina Cobo Castillo, Dorian Q. Fuller, Philip J. Piper, Peter Bellwood, Marc Oxenham

\begin{abstract}
Rach Nui is a late Neolithic settlement of hunter-gatherers in southern Vietnam. However, the site also has a series of mortared floors corresponding to a sedentary lifestyle, where the inhabitants continued to live in the same area and repaired or replaced their floors over a period of 150 years. The inhabitants relied on a mixed economy that included domesticated and gathered plants, as well as hunted and managed animals. Although, there is evidence for the consumption of domesticated rice and foxtail millet, the inhabitants were mainly huntergatherers who relied on their surrounding mangrove and swamp forest habitats for most of their food requirements. From the archaeobotanical work done, it appears that the domesticated cereals, rice and foxtail millet, found at the site were imported. On the other hand, sedge nutlets and parenchyma were identified in high frequencies and were probably locally sourced, suggesting that foraging and/or vegeculture played a major role in the economy of Rach Nui.
\end{abstract}

Keywords

Archaeobotany; Millet; Rice; Sedentary; Agriculture; Southeast Asia

\section{Introduction}

Discussions of transitions from hunting and gathering to farming are central to archaeology in all regions of the world (Barker, 2006; Bellwood, 2005 ; Larson et al., 2014). Early discourses suggested cultural shifts, including the uptake of farming, brought about by foreign colonisers into Europe where indigenous hunter-gatherers lived (Price, 2000). More recently, indigenous adoption has played a more significant role in the understanding of transitions in subsistence regimes (Price, 2000). This article appreciates that there are continuities between a hunting-gathering lifestyle and that of farming, as opposed to a strict dichotomy between hunter-gatherers and farmers (Harris, 1989).

In situations where domesticated plants and animals are inferred to be non-local in origin, their arrival is attributed either to a moving frontier of farmers migrating into a region sparsely inhabited by hunter-gatherers, or to a gradual adoption of agriculture by foragers due 
to interactions with adjacent farmers (Alexander, 1977; Zvelebil, 1986 ; Fuller, 2006, pp. 2$3)$.

The former of these hypotheses is most commonly invoked for the arrival of cereal agriculture in Southeast Asia (SEA). For example, although rice occurs wild throughout much of SEA, rice genetic studies and archaeobotanical evidence point to the origins of SE Asian domesticated rice in parts of the Yangtze basin by at least 4000 BCE (Fuller et al., 2010 ; Silva et al., 2015), prior to its later dispersal as part of a Neolithic cultural package that included incised and impressed pottery designs by migrating rice farmers from China, entering SEA and settling amongst the pre-existing hunter-gatherer communities, firstly in Taiwan and northern Vietnam, before spreading more widely (Bellwood, 2005; Rispoli, 2007; Higham, 2013; Higham et al., 2011). Some of the oldest Neolithic sites in Thailand and Vietnam contain evidence for the presence of rice, and, with the exception of the north Vietnamese site Man Bac, all Neolithic cranio-dentally analysed human material so far are of Northeast Asian or mixed Northeast Asian/Australo-Melanesian descent (Matsumura and Oxenham, 2014 ; Oxenham and Matsumura, 2016).

It has been suggested by Bellwood et al. (2011) that a 'Greater Mekong' cultural network linking Vietnam, Thailand and Cambodia existed from about 2500 cal BC. For example, the site of An Son, a southern Vietnamese Neolithic settlement dating from about 2100-1050 $\mathrm{BCE}$, has material culture, including pottery traditions, with parallels in other Neolithic sites in Vietnam (e.g. Loc Giang and Cu Lao Rua) and in Thailand (Tha Kae, Ban Non Wat, Nong Nor and Khok Phanom Di) [Sarjeant 2014]. Rice phytoliths have also been found in abundance at this site (Tan et al. 2012) as well as domestic pig and dog, which formed a major part of the subsistence at An Son (Piper et al., 2014). However, subtle differences between material culture repertoires, the geographic locations of raw material sourcing and socio-economic strategies are also becoming more apparent between various regional settlement groups in Mainland Southeast Asia (MSEA), implying relatively complex interactions between the different Neolithic communities that inhabited the region (see Sarjeant, 2014).

The earliest evidence of domesticated rice in MSEA is from the Thai coastal site Khok Phanom Di (ca. 2000-1500 BCE) where rice consumption was integrated into an economy focused on the exploitation of the mangrove environments surrounding the settlement (Higham and Thosarat, 2004). In the early phases of site occupation, rice appears to have been acquired through exchange, whereas later in the sequence local rice cultivation was adopted. Intriguingly, the adoption of rice cultivation coincided with the appearance of women whose isotopic signature suggests that they were immigrants into, what was presumably, the patrilocal society of Khok Phanom Di (Higham and Thosarat, 2012). However, the Khok Phanom Di community continued to use a diverse range of locally obtainable resources in the acquisition of their food supply. 
The inhabitants of MSEA, including those from Khok Phanom Di, possibly subsisted from older traditions of tuber cultivation such as taro and yams, as well as banana and palm starch (commonly known as vegeculture) that potentially first emerged in the Late Pleistocene or Early Holocene (Blench, 2013 ; Barton and Denham, 2011). Although there is currently no empirical evidence for vegeculture in early Neolithic sites in MSEA, there is starch and phytolith evidence for the consumption of palm starch, bananas, yams and sedge tubers (Eleocharis type), along with seed starches from job's tears (Coix lacryma-jobi) and acorns (Quercus sp. sensu lato) found on the ends of stone pounding tools at the site of Xincun in Guangdong in southern China, dating ca. 3350-2470 BCE (Barton, 2015 ; Yang et al., 2013), as well as very low frequencies of rice phytoliths recovered from sediments adhering to tools in deposits dating to ca. $2500 \mathrm{BCE}$ (Barton, 2015). Early sedentary communities in MSEA might have had similar mixed economies, which could have supported reasonably dense and well-adapted populations.

Recent archaeobotanical evidence has also indicated that foxtail millet (Setaria italica), which originated in the Yellow river basin of northern China, spread south like rice during the Neolithic ( Castillo; Castillo and Fuller, 2010; Weber et al., 2010; Guedes and Butler, 2014 ; Stevens and Fuller). Limited identification of foxtail millet in the archaeological record makes it difficult to determine the timing and routes of translocation across MSEA, but it has been recorded at Gantouyan on the border between southwestern China and Vietnam, together with rice, and dating ca. 2000-1000 BCE (Lu, 2009). The only other Neolithic record comes from the site of Non Pa Wai in the Khao Wong Prachan Valley, where a single foxtail millet grain was directly dated using AMS radiocarbon to 2470-2200 cal. BC (Weber et al., 2010).

In this paper, we will examine the archaeobotanical assemblage from Rach Nui, a late Neolithic site in southern Vietnam dating between ca. 1500 and 1300 cal. BC (Fig. 1). Rach Nui is located close to the town of Can Giouc, in Long A Province, near the estuarine confluence of the Vam Co Dong, Vam Co Tay and Dong Nai rivers, approximately $22 \mathrm{~km}$ from the modern coastline, to the southeast. The contemporary environment consists of lowlying mangrove and Nypa fruticans palm swamp forest, and small tidal channels surround the archaeological settlement site. In the past, Rach Nui would have been even closer to the sea and it is likely the local environment would have been very similar ( Piper and Oxenham, 2014). Rach Nui provides an opportunity to examine the potential diversity of subsistence regimes practiced in the later Neolithic period, when domesticated cereals had already been introduced into MSEA but also taking into consideration the environment of the settlement. The archaeobotanical research conducted at Rach Nui makes it possible to understand the type of subsistence strategies used during this early period, which has parallels in some other MSEAsian sites. It is therefore, an important site for discussions about adaptations of people to their environment for food procurement and possibly, transitions from a hunter gathering lifestyle to one of farming or vice versa (see Table 1 for the list of sites mentioned in the text).

\section{Archaeobotany of Vietnam}


Archaeobotany as a specialization in Southeast Asia began in the late 1960s (Castillo and Fuller, 2010). Archaeobotanical methods, including flotation, phytolith and pollen sampling are still not routinely used in archaeological fieldwork in Southeast Asia, although in the past ten years they have gained momentum. In Vietnam, few archaeobotanical studies have been conducted. From published data and personal communication, only forty-three sites in Vietnam have employed any method (such as looking at pottery impressions), which could result in the observation of plant remains (Table 2). In Vietnam, as in the rest of Southeast Asia, organic impressions in pottery have been relied upon to understand the agriculture of the region. However, using rice chaff or impressions as a method does not provide sufficient information and can result in misleading interpretations (Castillo, 2013). Of these forty-three sites, phytolith sampling was done in ten sites but not all of them have been analysed, whereas fourteen sites have been sampled for palynology. Wet and dry-sieving have been used in the past for recovery of macroremains, but it was only in 2007 that flotation was used to investigate potential palaeobotanical remains within the burial pots during the Man Bac excavations. The 2012 excavations at Rach Nui was the first time systematic flotation for the retrieval of macroremains had been applied in Vietnam. There are now seven sites, including Rach Nui, where flotation has been conducted.

The archaeological analysis of plant remains from Rach Nui contributes to our understanding of what crops were consumed in Neolithic Southern Vietnam. Academic research has assumed that the main crop of cultivation in prehistoric Mainland Southeast Asia was rice (Glover and Higham, 1996 ; Higham, 2013), and although this may be true for some sites, more archaeobotanical research is needed to support this general hypothesis. For instance, foxtail millet or taro could have also been a major crop in prehistory. This is highlighted in Central Thailand where the site of Khok Phanom Di has yielded abundant rice remains (Thompson, 1996), whereas Non Pa Wai, Non Mak La and Nil Kham Haeng in Central Thailand have produced evidence for consumption and cultivation of foxtail millet, prior to the introduction of rice (Weber et al., 2010). These examples suggest that rice was not the only cereal being consumed during the Neolithic. Therefore, a significant question in Rach Nui was whether both cereals are also found in southern Vietnam in the Neolithic. Presence of both cereals could confirm the movement of a crop package from the southern China/northern Vietnam region into the Mekong Delta region of southern Vietnam.

\section{Methodology and sample integrity}

\subsection{Sampling}

Fieldwork, including archaeobotanical sampling and flotation, took place at Rach Nui from March to April 2012. Four trenches were excavated and sampled. This article discusses the macrobotanical remains analysis from one trench (Trench 1). Bulk soil samples for the macroremains analysis were collected from several quadrants (Fig. 2). The aim was to collect a standard amount of soil in every layer or feature from the quadrants chosen for archaeobotanical sampling to obtain chronological information. Where possible, all layers and features were sampled including those from less productive deposits as a control measure (after Popper and Hastorf, 1988). This provides chronological resolution but also, stratigraphic information.

Sampling continued until a sterile layer was reached. As inferred from cultural material and other biological remains, the lowest layer to contain evidence of human activity is F135. An average of $8.13 \mathrm{~L}$ of soil was collected and floated per layer or feature (Table 3). Ideally, the amount of soil collected per stratigraphic unit in tropical environments averages $40 \mathrm{~L}$ (e.g. 
Ban Non Wat and Khao Sam Kaeo; after Castillo, 2013). Preservation is a problem in these environments and collecting and floating more soil normally increases the number of charred remains retrieved. However, at Rach Nui Trench 1, it was not always possible to collect high volumes of soil per layer because these were found to be thin or shallow (Appendix A) and time constraints imposed on the length of excavation time. Many layers were soils found in between the solid surfaces embedded in the platforms (see Fig. 3).

The soil collected from each context was not dried or dry-sieved prior to flotation to lessen contamination and loss of material and the method used was simple washover bucket flotation. The bags used for flotation were made from mesh measuring $250 \mu \mathrm{m}$. The remaining heavy fraction resulting from flotation was wet sieved. Wet sieving is also used when dealing with waterlogged botanical remains ( Pearsall, 1989). This method was therefore used since it was believed a priori that the remains found in some layers of the site would be waterlogged because of the proximity of the trench to a fishpond. Also, Rach Nui lies $c a$. $2.34 \mathrm{kms}$ from the Cần Giuộc River located to the west of the site. The lands are relatively flat and prone to flooding. The faunal remains were sorted from the wet sieved heavy fraction along with shell, pottery and the other cultural material.

\subsection{Site description}

The excavation of Trench 1 unearthed a layer of disturbed reworked Neolithic deposits mixed with more recent materials close to the modern ground surface, overlying a series of at least 14 solid surfaces and platforms that appear to have consisted of floors produced from a mixture of pottery fragments, sediment, and possibly shell lime mortar (Oxenham et al., 2015). These platforms were all orientated north-south and built consecutively one on top of the other. Numerous postholes and beam slots around the margins of the house platforms indicate light fences possibly surrounded them, and large and small postholes in platform surfaces imply structures were built on them. The morphology of some organic impressions in the floors possessed nodes, indicating that bamboo had been the material of choice, at least for lighter construction. The construction of a new raised surface and associated features involved the complete demolition of pre-existing structures. Between successive platforms were thin black layers of sediment with very high concentrations of charcoal and wood ash. In addition, high concentrations of wood charcoal were mixed with the lime mortar and pottery fragments. These charcoal inclusions in the mortar have been interpreted to come from possible burning episodes of mollusc shell, a process used in the creation of lime mortar (Oxenham et al., 2015). There are impressions and silicified remains of organic material visible in some of the layers from Trench 1, as well as floors made of wood (Fig. 4).

Rach Nui is situated close to where three rivers meet and can be described as an island because it is a mound surrounded by flat alluvial land prone to flooding. The site is located in a tidal swamp habitat consisting of nipa palm and mangrove wetland forests. Mangrove forests are situated between land and sea and are specifically adapted to saline and brackish water. These types of forests are mainly found along coastlines, river mouths and slightly inland where rivers are influenced by the tides. They are rich habitats providing a wide range of plants and animals of economic importance. At Rach Nui, management and exploitation of the surrounding mangrove forests would have provided an adequate supply of food items and construction material. However, a tidal swamp habitat is not an ideal location to engage in cereal farming due to increased saline conditions that decrease cereal productivity. 
During the archaeobotanical analysis large quantities of termite frass was recorded in $79 \%$ of the samples. As discussed in the results section, the activities of termites might have been one of the root causes of the substantial burning episodes recorded at Rach Nui.

Based on the Bayesian analysis of 17 radiocarbon dates on wood charcoal, the settlement stratigraphy is anchored to a solid chronology indicating occupation between ca. 1500 and 1300 cal. BC (see Oxenham et al., 2015: Fig. 3).

\subsection{Datasets, preservation and context security}

A total of thirty-three samples collected from flotation were sorted, analysed and interpreted. The botanical macroremains results show low diversity with low numbers of taxa and plant parts per litre (see Table 3). Preservation is generally poor in humid tropical environments as is the case in another Southeast Asian site located in the Southern Peninsula of Thailand, Khao Sam Kaeo, which has an average of 8.74 plant parts per litre (Castillo, 2013). Rach Nui has an even lower average than Khao Sam Kaeo of 4.11 plant parts per litre, which could be due to either preservation or taphonomic issues. Trench 1 was excavated in a settlement area and although settlement areas are usually expected to be rich in macroremains because food is processed, cooked and disposed of there, it is possible that the inhabitants at Rach Nui kept their living quarters in Trench 1 clean by sweeping their floors regularly.

The term 'presence' or 'presence-analysis' is used to denote the total number of occurrences and 'ubiquity' is the percentage of these occurrences.

In order to determine context security, an analysis of modern seeds, proportion of roots and fungal sclerotia was done (after Castillo, 2013). Bioturbation is a limitation encountered in archaeobotany attributed to burrowing animals and roots that push seeds (both modern and archaeological) downward. Therefore, seeds that are not charred or silicified are considered modern and recorded accordingly. However, sometimes, modern seeds make their way into the samples during flotation via wind if the area where flotation takes place is surrounded by fruiting vegetation. It is important to note one's surroundings whilst doing fieldwork to determine how modern seeds ended up in the samples. The proportion of modern roots in each sample was recorded, as well as the presence of fungal sclerotia. Fungal sclerotia are the hard-bodied stage of fungus found in well-aerated moist soils (Fig. 5). Their presence at the site of Khao Sam Kaeo in Peninsular Thailand is considered to be an index of bioturbation and is likewise used in the Rach Nui analysis.

High levels of inclusions are first determined by looking at the percentage of modern seeds per sample. A level greater than $15 \%$ is considered high. Normally, a high proportion of roots in the samples results in a higher percentage of modern seeds, as is the case in sample ' $\mathrm{H} 1$ F41/1 A1 at Rach Nui.' Table 4 shows the levels of bioturbation per context with contexts ordered chronologically from most recent to oldest in the stratigraphic sequence. It is clear from the table that the more recent sequences or contexts that are closer to modern ground surface have higher percentages of modern plant remains and roots, whereas the contexts belonging to the oldest sequences are free of roots and modern plant remains. The analysis shows that overall there are low levels of bioturbation in Trench 1 (Table 4) perhaps because this trench corresponds to a settlement area where the past construction of solid surfaces restricted deep penetration by roots and burrowing animals. In fact, the hard surfaces were extremely difficult to excavate, and it was often necessary to break them up with a pick (Oxenham et al., 2015). Only four samples show potential modern contamination: H1 F41/1 A1, H1 L18 c.1018 C4, H1 L19/1 A4 1019/1 and H1 F2E A7 (Table 4 highlighted) and results from these particular samples are considered with caution. 


\section{Results and discussion}

\subsection{Subsistence regime: domesticated cereals}

Rach Nui was a sedentary community that adapted to their local environment not only in the building techniques in constructing habitations, but also for their economic requirements. Results of the zooarchaeological research indicates that various subsistence strategies were used, including the consumption of domesticated pigs and dogs, and the hunting of locally available wild animals such as monkeys, crocodiles and turtles (Oxenham et al., 2015). However, the majority of the protein diet probably resulted from the consumption of a variety of fish including large quantities of snakeheads and catfish that could have been trapped within the tidal swamp forests surrounding the settlement. The mollusc assemblage consists almost entirely of the bivalve Geloina coaxans and the gastropod Cerithidea obtusa. Both these species of shellfish are common in mangrove environments and indicate, as does the terrestrial vertebrate remains, that resources were acquired locally.

The botanical assemblage shows consumption of a combination of domesticated crops and wild plants. There are two domesticated economic crops present at Rach Nui, the cereals Oryza sativa (rice) and the small millet Setaria italica (foxtail millet). Whole grains, fragments and other plant parts of these cereals were identified. However, rice husk (impressions and silicified) dominates the rice assemblage. Whole and fragmented grains of foxtail millet were identified but no husk. Table 5 shows the economic crops identified and a summary of the weeds that occur in the same contexts defined by their habitat.

Rice was identified in eight samples from thirty-three contexts, corresponding to a ubiquity of $24 \%$ (Table 5). The breakdown of rice plant parts shows overall low frequencies of rice remains. And although rice plant parts have a higher ubiquity than foxtail millet, this does not suggest that rice was a more important economic crop than foxtail millet. As charring experiments have shown, there is a preservation bias in favour of husked rice compared to foxtail millet (Castillo, 2013). Foxtail millet husk and spikelet bases rarely preserve. The majority of the rice remains was made up of husk, although three domesticated-type rice spikelet bases were also found showing irregular gouged out scars (Fig. 6). The presence of husk (Fig. 6) and spikelet bases means that the rice was stored as spikelets, as these represent rice processing waste products.

We are unable to distinguish the rice in Rach Nui as either japonica or indica-type as only one badly preserved rice grain was identified ( Fig. 7). A larger dataset is necessary for a morphometric study but also the results would not be conclusive without aDNA fingerprinting. Domesticated rice in Mainland Southeast Asia during the same period is present in other sites such as at Ban Non Wat and the Khao Wong Prachan Valley, and earlier in Khok Phanom Di. An archaeogenetic study conducted on rice grains from four sites spanning the Bronze Age to the Iron Age in Thailand confirms rice to be japonica ( Castillo et al., 2016a). It is therefore also likely that rice from earlier periods in MSEA, including from Rach Nui is the Chinese originated, Oryza sativa spp. japonica.

There is no evidence to suggest cultivation was taking place in Rach Nui or its vicinity. The rice was probably brought into Rach Nui through exchange. The mollusc report (Piper et al., 2013) shows that a type of gastropod Pila cf. ampullacea does not occur in the Neolithic levels (with the exception of two possibly intrusive specimens) but is present in the upper 
layers. This is significant since these are gastropods normally found in rice paddy fields and irrigation canals and commonly eaten in the region today ( Piper et al., 2013). The absence of these gastropods does not necessarily mean that rice consumed at Rach Nui was not cultivated in wetland agricultural systems, but it likewise does not confirm wetland systems of agriculture to be present. Furthermore, only three contexts containing rice had associated weeds of cultivation and the weeds represent both dryland and wetland habitats (Table 5). As noted above, the only Mollusca identified in quantity at Rach Nui are mangrove species that inhabit brackish water environments. Even today, all the rivers and streams around Rach Nui are strongly tidal and contain brackish water. Freshwater is uncommon in the region and is extracted via deep wells or comes from rainwater during the rainy season (personal communication, Tran Thi Kim Quy, 2016). It is unlikely that freshwater was that much easier to come by 3500 years ago, and the environments around Rach Nui were probably unsuitable for rice agriculture due to salinity. Salinity decreases rice productivity probably due to osmotic stress, which suppresses germination and ionic stress, which affects photosynthesis ( Horie et al., 2012 ; Zeng and Shannon, 2000). At present, salinity remains one of the major challenges towards increasing rice yields and plant breeders have bred popular varieties of rice, which include the gene Saltol (short for 'salt tolerance') to create more salt tolerant rice ( Thomson et al., 2010).

The two contexts (12RNH1 L16 B3 1016; 12RNH1 L18 c.1018 C4) that contained foxtail millet represent charcoal layers underneath one of many floors found at Rach Nui. These contexts did not contain any rice plant parts. Context 12RNH1 L16 B3 1016 lies between dated contexts and has been estimated to belong to $c a$. 1400-1300 BCE sequences. Rice was found in 12RN H1 L34/1 C3 1034/1, the basal layer of Trench 1, indicating the inhabitants of Rach Nui had access to this cereal crop from the earliest phases of occupation at ca. 1500 cal. $\mathrm{BC}$.

Foxtail millet grains are small measuring $c a .2 \mathrm{~mm}$ in diameter, have an oval and plump shape and an embryo spanning $2 / 3$ to $3 / 4$ the length of the grain ( Fuller,

2002; Fuller ; Zohary et al., 2012). Charred archaeological samples are expected to be smaller than fresh samples due to several factors including shrinkage, especially length, caused by charring ( Bowman, 1966; Braadbaart, 2008 ; Castillo, 2013). The measurements of the archaeological specimens from Rach Nui match the criteria stated above including the average embryo to length of grain ratio averaging $75.31 \%(n=6$; Table 6). Table 7 shows average measurements of foxtail caryopses from Rach Nui, Metal Age Khao Sam Kaeo in Peninsular Thailand and modern measurements. The Rach Nui caryopses are slightly smaller than the modern grains.

The grains from Rach Nui can be clearly identified as foxtail millet by the long embryo (Fig. 8). Another characteristic of foxtail millet which was unfortunately not noted in the archaeological specimens as they had no adhering husk is a finely rugose lemma.

The small millet, Setaria italica, was domesticated $c a .6000$ BCE in northern China from the

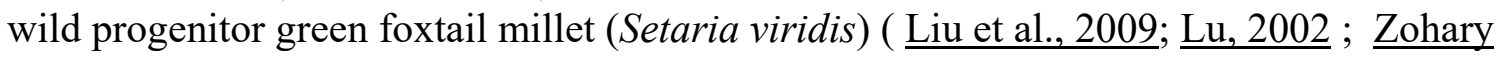
et al., 2012) although recent work using starch grain analysis from Nanzhuangtou and Donghulin has put back the date for foxtail millet exploitation by at least two millennia (Yang et al., 2012). Early finds of foxtail millet in northern China include charred grains at Xinglonggou, and Yuezhuang ca. $6000 \mathrm{BCE}$ and many sites situated in the Yellow River basin dating from 5500 to $1300 \mathrm{cal} \mathrm{BC} \mathrm{(} \mathrm{Lee} \mathrm{et} \mathrm{al.,} 2007$; Liu et al., 2009). There is also evidence of the spread of foxtail millet alongside rice in sites dating to the early third 
millennium in Taiwan ( Fuller et al., 2010 ; Tsang, 2005). Rice and millets do not co-occur in archaeological sites in the Lower Yangtze suggesting that foxtail millet did not spread into Taiwan from that region (Fuller et al., 2010), but perhaps rather through the middle Yangtze and southwards into MSEA (Fuller et al., 2010). This hypothesis is tentatively supported by the recovery of foxtail millet at the site of Chengtoushan located in the middle Yangtze dating to $c a .5800 \mathrm{cal}$ BP ( Nasu et al., 2007), and at Gantouyan (found together with rice) on the border between southwestern China and Vietnam, dating to 2000 to $1000 \mathrm{BCE}$ ( $\underline{\mathrm{Lu}}$, $\underline{2009})$.

Unlike rice, the evidence for foxtail millet in MSEA is more limited, with all of the sites located in Thailand. The earliest evidence comes from Non Pa Wai in the Khao Wong Prachan Valley where a single foxtail millet grain was directly AMS radiocarbon dated to 2300 BCE (Weber et al., 2010). Non Pa Wai and two other sites in the Khao Wong Prachan Valley, Nil Kham Haeng and Non Mak La, have evidence of foxtail millet during the Bronze Age Period (Weber et al., 2010). During the Metal Age, Khao Sam Kaeo located in peninsular Thailand has yielded evidence of foxtail millet (Castillo and Fuller, 2010 ; Castillo et al., 2016b). The dearth of millet evidence could be due to several factors including preservation biases, recovery techniques that use sieves with perforations larger than $250 \mu \mathrm{m}$ or simply that millets were not being consumed or cultivated at particular settlement sites. On the current archaeobotanical evidence it seems that foxtail millet was being cultivated up to a millennium earlier than rice in Central Thailand (Weber et al., 2010). These disparate arrival times for rice and foxtail millet in Central Thailand also suggests that the spread of cereal agriculture across the region was complex and likely entailed spatial and temporal variability in the translocation of crops (Castillo, in press).

The identification of foxtail millet at Rach Nui is significant as it is the first clear evidence for the presence of this cereal in Vietnam during the later Neolithic. This is possibly because systematic flotation has not been practiced in previous archaeological investigations in Vietnam. But, the presence of a small quantity of foxtail millet found in only two contexts demonstrates that foxtail millet, like rice, was known and consumed but not necessarily cultivated. Furthermore, the extent and type of consumption (e.g. ceremonial vs. staple food) is not known. The likelihood is that with more archaeological excavations employing flotation as a principle recovery strategy for palaeobotanical remains, a greater number of sites will yield evidence of foxtail millet and its southward dispersal route(s) will be revealed in due time.

\subsection{Subsistence regime: gathered food products}

There was an abundance of unidentified plant remains at Rach Nui, although some have been grouped into types, parenchymatous, mesocarp and fruit fragments. Parenchymatous and mesocarp fragments were found in $70 \%$ and $24 \%$ of the contexts respectively and make up $28 \%$ of the total plant part assemblage (Fig. 9). This high representation signals the use of tubers and fruits. On the other hand, cereals under the heading 'economic crops' make up only $2 \%$ of the total assemblage. Therefore, when presence-values and ubiquity of parenchymatous, mesocarp and fruit fragments are compared to those of economic crops, it appears that the subsistence regime in Rach Nui was more reliant on gathered or vegecultural resources rather than cultivated cereals. This scenario accords well with the zooarchaeological analysis that indicated foraging, fishing and hunting activities played a prominent role at Rach Nui (Piper et al., 2013 ; Piper and Amano, 2013). It is considered that the inhabitants of Rach Nui were exploiting locally available plant and animal resources. 
Parenchyma consists primarily of vegetative organs such as roots, tubers, rhizomes and corms, whereas mesocarp fragments represent mostly the edible part of a fruit usually fleshy and succulent. The charred parenchyma found in Trench 1 is in the form of rounded fragments with spherical cells that can be seen using a low powered microscope (after Hather, 1991). The shape and the size of the cells, the thickness of the cell walls, and the presence of cavities are some of the criteria used to identify parenchyma (Hather, 1991). The parenchymatous fragments from Rach Nui measure less than $1 \mathrm{~cm}$ making identification a difficult task. A preliminary attempt to identify parenchymatous fragments was undertaken and a few fragments have been identified as storage organ parenchyma tissue (Fig. 10). However, more parenchymatous fragments should be analysed in order to have an understanding of root use. The fruit fragments are charred and still have small seeds attached (Fig. 11). Other fragments have cavities where the seeds would have been. The fruit fragments have not been identified yet.

The sedge, Scirpus sp. sensu lato (probably of the genus Schoenoplectus) is reported as a separate find because the seeds occur in high frequencies. One context late in the chronological sequence (L15 A4 1015) yielded 145 seeds. The lowest sequences in Trench 1 do not contain any seeds. The evidence for Scirpus sp. starts in layers associated with the Phase 8 construction and dates to ca. 1500 BCE onwards. Sedges were found in $47 \%$ of the samples from Trench 1 . These specimens were made up predominantly of small charred nutlets without the pericarp or embryo, and measure ca. $0.7 \times 0.66 \mathrm{~mm}(\mathrm{n}=3)$. The nutlets are globose with a dimple on the top end and a convex scar on the lower end where the embryo would have attached ( Fig. 12 B). The nutlets are flattish in proximal view. The surface is reticulate-areolate or granular. A nutlet still had the embryo attached to it. The embryo is in the shape of a peak with horizontal ridges (Fig. 12 A). The embryos were probably detached as a result of carbonisation and seed processing. Similarly, in the rice crop-processing stage involving dehusking, the rice caryopses normally lose their embryos. Identification to species is necessary to ascertain the economic importance of Scirpus sp. sensu lato as human food, but the evidence that removal of the pericarp was taking place suggests these seeds were being processed and consumed as part of the diet.

Scirpus nutlets were also reported from Khok Phanom Di, and Thompson considered the finds weedy and representative of a swampy ecology, rather than for economic use ( Thompson, 1996). Although they are probably representative of the nearby swampy ecology at Khok Phanom Di, given their high frequency and the large proportion of nutlets without the pericarp, they also suggest crop processing (such as pounding). It is suggested here that the Khok Phanom Di sedges have a similar function to those from Rach Nui, as a food. Fig. 12 shows the images of the sedges found at Rach Nui (see Thompson, 1996: 114115, Figs. 17-5,18-1,18-2 for comparison). The sedges found at both sites are comparable in size, shape and texture. That sedges are found in both sites is not surprising considering that the ecosystems exploited during the Neolithic were similar. Khok Phanom Di was located close to an estuary and had access to mangrove and swampy areas (Thompson, 1996) where wild resources could have been gathered, whereas Rach Nui is adjacent to tidal rivers, composed of mangrove and Nypa fruticans swampland where considerable number of the animals consumed at Rach Nui were sourced from ( Oxenham et al., 2015). The site of An Son has evidence of sedge phytoliths although they have not been interpreted to form part of the food supply (Tan et al. 2012). The phytolith study from An Son also shows a possible dependence on non-grass plants, including bananas, palm and bamboo, before the establishment of rice cultivation (Tan et al. 2012). 
A few sedge nutlets from Rach Nui were found with their pericarp still intact. These nutlets displayed the typical ovate shape of the genus Scirpus, as well as a blunt style base (Fig. 12 C) [Martin and Barkley, 2000]. One nutlet with a fractured pericarp showed the cotyledon in the interior (Fig. 13). A rhizome detachment scar possibly of Scirpus sp. sensu lato was also found in the archaeobotanical assemblage ( Fig. 13). Although only one example of a rhizome was found, it is likely that tuber and rhizomes were important food resources during the Neolithic. We considered twenty-three sedge species commonly found in Asian tropical environments to plot their flowering, fruiting and tuber formation periods (belonging to the genera Schoenoplectus, Bolboschoenus and Scirpus) [ Fig. 14]. For a hunter-gatherer community, Cyperaceae plants are a good source of food all year round. Nutlets are gathered during the wet season months August to October whereas tubers are gathered during the winter and summer season (January to April) making this a very useful subsistence resource.

There are several examples of plants from the Cyperaceae family with economic uses in Southeast Asia and elsewhere (Simpson and Inglis, 2001). The main uses are nutlets, tubers and rhizomes for food, and culms and stems as material. Culms and leaves of some species are also eaten, and other uses include food additives, medicine, fodder, fuel, soil improvers and ornamental (Simpson and Inglis, 2001). Burkill (1935) reports the whole plant of Scirpus grossus can be used for green manuring, its tubers eaten or prepared as a medicine and the stems used for matting and string. The triquetrous culms of Schoenoplectus mucronatus (syn. Scirpus mucronatus) are used for mat making and string, especially in China and West Malesia ( Burkill, 1935 ; Simpson and Koyama, 1998). Thompson (1996) reports that corms of Eleocharis and Cyperus are eaten in Thailand raw, boiled or roasted. The nutlets of Schoenoplectus dissachanthus are eaten as food in Australia whereas the rhizomes of Schoenoplectus littoralis are cooked as a vegetable in Oman ( Simpson and Inglis, 2001). Finally, it is well documented in the Near East, that the nutlets, shoots and tubers of Bolboschoenus maritimus or sea club-rush, as well as those of Bolboschoenus glaucus, were eaten in prehistory ( Wollstonecroft et al., 2008). Nutlets of B. glaucus, widely reported from Pre-Pottery sites in West Asia, might also have sometimes been eaten ( Wollstonecroft et al., 2011). The use of rhizomes and tubers as food are frequently referred to as 'famine food.'

Plants belonging to the genus Scirpus are also used for matting. However, the evidence of nutlets in Rach Nui suggests food use, although it is plausible that sedges would have also been used as materials for matting or bedding. Analysis shows that if matting was the main economic use, the plants would be harvested young and not whilst seeding. The young or immature leaves are softer, more malleable and easier to manipulate. Furthermore, there would be no need to process nutlets for matting purposes. However, the use of Scirpus for matting as well as food is not discounted. The plants would be gathered as leaves and not nutlets and might not leave an archaeological signature using macroremains analysis unless impressions of the leaves remain visible in the mortar. The phytolith study ( Weisskopf, 2016) revealed a large proportion were from sedges, which may signify the use of Scirpus for matting.

\subsection{Weed analysis: ecology or farming systems}

Weeds are useful markers to determine the farming systems used in the past (Castillo, 2011 ; Colledge, 1994). However, the weeds need to be associated with economic crops. 
Otherwise, the weed analysis can be used as a good descriptor of the ecology where the site is located. At Rach Nui, the weed assemblage was narrowed down to eight taxa with low frequencies. Four were identified to species, two to genus and two to family. The majority of weed species represented at Rach Nui Trench 1 are normally found in dryland or upland environments but there are a few hydrophilic weeds and weeds found in both wetland and dryland environments present in the samples (Table 8). There are a few samples containing economic crops and associated weeds in the same context (Table 5). However, frequencies of both the economic crops and weeds are low. Also, as discussed in the rice and foxtail millet sections, it is believed that cereal cultivation did not take place in Rach Nui. It is therefore not possible or necessary to carry out a weed analysis to determine the type of farming system that may have been in place (wetland or dryland). The weed assemblage most likely represents weedy species that were gathered for food and material (e.g. Scirpus sp. sensu lato) or weeds growing in the surrounding habitat and may therefore represent the ecology in the immediate vicinity of Rach Nui. Images of weeds identified to species are found in Fig. 15. However, the same limitation as with defining farming systems applies to identifying the ecology of the area in the case of Rach Nui. Like rice and foxtail millet, the representation of weed taxa in Rach Nui is limited to a few seeds of each species $(\sim 1-3$ per species) except for Scirpus sp. sensu lato $(\mathrm{n}=235)$.

\subsection{Other finds}

High frequencies of termite frass were found in 23 contexts at Rach Nui Trench 1 with a ubiquity of $77 \%$. Frass is found from the earliest to the latest levels and make up $18 \%$ of the total archaeobotanical assemblage (NSP $=1343$ ) [Fig. 16]. The frass pellets are oblong with hexagonal cross-sections and measure $c a .459 \mu \mathrm{m} \times 300 \mu \mathrm{m}(\mathrm{n}=2)$. They are charred or silicified, found in clusters or as discreet units. The archaeological frass was identified as drywood termite frass ( Woodrow et al., 1999) and is comparable to modern drywood termite frass collected at the Forestry Department in Los Baños, Philippines (Fig. 17). Drywood termites live in close association with humans and the termite frass preserves well and has been found in geological deposits dating to as early as the Upper Cretaceous in west Texas (Rohr et al., 1986), and the mid -Tertiary rainforest in Australia (Rozefelds and De Baar, 1991). Archaeologically, they have been previously described from the southwestern United States (Adams, 1984) and Mesolithic Portugal (Lopez-Doriga, 2015: 454).

The different colours in Fig. 16 represent phases of construction and the spikes $(\geq 50 \%$ termite frass) may represent burning episodes although this needs to be confirmed. The presence of termite frass in substantial quantities suggests that the Rach Nui settlement had termite infestations. One possible method to control termite infestations as well as alleviate encroaching damp at Rach Nui was to periodically burn down dwellings and reconstruct from the ground upwards. If we consider that the succession of 13 platforms and surfaces recorded in Trench 1 were replaced regularly between ca. 1500-1300 cal. BC, then complete demolition and reconstruction would have occurred every $\sim 15$ years. The replacement of posts and other structures is also evident, and this would probably have occurred on an even more regular basis, as was the patching of floor surfaces. The excavations in Trench 1 show that there were several burning episodes that took place during the duration of human settlement. We propose the inhabitants potentially used fire as one form of pest control.

\section{Conclusions}


The archaeobotanical assemblage at Rach Nui came from secure contexts and like other Southeast Asian sites where macrobotanical analyses have been conducted, showed poor preservation of plant remains. Nevertheless, several taxa allow for a reconstruction of the subsistence regime in this site, dating to the late Neolithic period. Both domesticated cereals and gathered wild plants were consumed but differed in their contribution to people's daily diet. The only domesticated cereals found in low frequencies and only in a few samples are rice and foxtail millet, originating far to the north in the Yangtze and Yellow River basins respectively. In contrast, the evidence for wild resources had higher frequencies and ubiquity values than those of the domesticated cereals indicating a reliance on fruits, roots and sedges. These wild plant resources were exploited in the vicinity of Rach Nui, including the mangrove forests.

The vast number of fish bones recovered from Rach Nui are of local brackish-water tolerant fish such as catfish, snakeheads and climbing perch caught in the small tidal river channels close to the settlement and provided most of the protein diet. Fish was supplemented by hunted turtles, monkeys and crocodiles, and by the maintenance of pig and dog populations. The presence of rice and foxtail millet indicates that the Rach Nui community had access to these cereals, but the low frequencies of these crops and the environmental constraints for cereal farming suggest these were imported rather than cultivated locally. Rice has a very low tolerance to saline soils (Zeng and Shannon, 2000) and the lack of freshwater coupled with high soil salinity within the tidal swamp forests surrounding the settlement would have made it difficult to cultivate close to Rach Nui. On the other hand, the presence of relatively high proportions of sedge nutlets and parenchyma supports the faunal data in suggesting that foraging and/or vegeculture played a major role in the economy of Rach Nui.

Mainland Southeast Asia was colonised ca. 50-60,000 years ago by the more or less direct ancestors of contemporary indigenous Australians and Melanesians, thus the term 'AustraloMelanesian' is used to describe the majority of pre-Neolithic human remains from MSEA (Matsumura and Oxenham, 2014; Oxenham and Buckley, 2016). From ca. 2300 BCE onwards we begin to see the emergence of a new wave of colonisers who can be distinguished by a suite of morphological and genetic characteristics that indicate direct descent from Northeast Asian populations (Matsumura and Oxenham, 2014). The emergence of these new migrants coincides with the first evidence for rice near the China/Vietnam borderlands ca. $2250 \mathrm{BCE}$, based on a diffusion process modelled from available rice archaeobotanical evidence [330 sites across Asia] (Silva et al., 2015). Indeed, there is a wealth of support for the role of the Neolithic demographic transition (NDT) and expansion of farming societies into MSEA (Bellwood and Oxenham, 2008; see also Higham and Rispoli, 2014 ; Rispoli, 2007).

The Neolithic cemetery of Man Bac in Northern Vietnam contained members from two population sources at $2000 \mathrm{BCE}$, and was probably occupied at the very cusp of the admixture process between immigrant southern farmers of Northeast Asian descent and indigenous Australo-Melanesians, according to cranio-dental, isotopic and aDNA analyses (Oxenham et al., 2011). With the exception of Man Bac, all the cranial and dental analysis of human remains from Thai and Vietnamese Neolithic sites are of Northeast Asian or mixed Northeast Asian/Australo-Melanesian descent. However, identification of the inhabitants of Rach Nui as Australo-Melanesian, Northeast Asian or mixed descent cannot be confirmed due to the lack of human skeletal remains. In order to gain more insights as to the biological make-up of the inhabitants of Rach Nui, there is a need for more archaeological fieldwork in the surrounding area. 
What we can say is that from its inception, the inhabitants of Rach Nui were familiar with sedentary settlement construction and planning, and perhaps colonised the lowland swamps of the Mekong Delta region from pre-existing settlements in the region (Piper and Oxenham, 2014). The settlement consists of a series of raised floor surfaces and timber-framed structures, where the inhabitants continued to construct and repair their dwellings over a period of perhaps 150 years. The environment where the site is located was prone to flooding and termite infestations, which would have required constant attention. The location of Rach Nui in a mangrove forest/tidal swamp ecology would have provided the inhabitants a diverse diet and a variety of locally sourced key products, but would also have been a major constraint in terms of living conditions and farming. The site was well connected both inland and to the sea via the adjacent river system although there is no evidence that the inhabitants went to the coast to procure food supplies. However, interconnectivity is evident from the domesticated cereals and fine ware pottery found on site but probably coming from elsewhere, particularly the Dong Nai region (Sarjeant, 2014). It is possible that Rach Nui exchanged locally sourced or processed items for cereals and pottery.

Whether the first settlers were farmers who switched to hunting and gathering or were huntergatherers from the establishment of the settlement will remain unresolved for the moment, as it is not evident in the archaeology of Rach Nui. However, we can suggest these huntergatherers were adapted to their environments by sourcing most of their dietary requirements from their surroundings but interacted with cereal farmers to acquire domesticated rice and millet.

\section{Acknowledgments}

This study would not have been possible without the help from Ma. Jasminda Ceron who undertook flotation in Castillo's behalf when she left Vietnam for an emergency. We would also like to thank Bùi Chí Hoàng, Nguyễn Khánh Trung Kiên and Nguyễn Quốc Mạnh from the Centre for Archaeological Studies, Southern Institute of Social Sciences, Vietnam; Glenn Estudillo from the Forest Products Research and Development Institute (FPRDI); and Marciana R. San Pablo, Karina G. Bueser, and Sheryll C Micosa from Biodeterioration and Protection Section, Material Science Division, Forest Products Research and Development Institute (FPRDI) in Los Baños, Philippines for helping Castillo acquire modern termite frass. Lastly, we would like to thank Andrew Fairbairn and Ofer Bar-Yosef who held the UQHarvard Symposium at the University of Queensland, 23-25 March 2014 and where two of the authors were invited to participate. This research was supported by the Australian Research Council Grant \# FT120100299 and the Natural Environment Research Council (NERC) Grant \# NE/K003402/1.

\section{References}

References

Adams, K.R., 1984. Evidence of wood-dwelling termites in archaeological sites in the southwestern United States. J. Ethnobiol. 4 (1), 29e43. 
Alexander, J.A., 1977. Frontier concept in prehistory: the end of the moving frontier. In: Megaw, J.V.S. (Ed.), Hunters, Gatherers and First Farmers beyond Europe. Leicester University Press, Leicester, pp. $25 \mathrm{e} 40$.

Barker, G., 2006. The Agricultural Revolution in Prehistory: Why Did Foragers Become Farmers? Oxford University Press, Oxford.

Barton, H., 2015. Early agriculture in Southeast Asia and the Pacific. In: Barker, G., Goucher, C. (Eds.), The Cambridge World History Volume 2: A World with Agriculture, 12,000 BCEe500 CE, Cambridge University Press, pp. 411 e444.

Barton, H., Denham, T., 2011. Prehistoric vegeculture and social life in island Southeast Asia and Melanesia. In: Barker, G., Janowksi, M. (Eds.), Why cultivate? Anthropological and archaeological approaches to foragingefarming transitions in Southeast Asia. McDonald Institute for Archaeological Research, Cambridge, pp. 17e25.

Bellwood, P., 2005. First Farmers: the Origins of Agricultural Societies. Blackwell, Oxford.

Bellwood, P., Oxenham, M.F., 2008. The expansions of farming societies and the role of the Neolithic Demographic Transition. In: Bocquet-Appel, J.-P., Bar-Yosef, O. (Eds.), The Neolithic Demographic Transition and its Consequences. Springer, Dordrecht, pp. 13e34.

Bellwood, P., Oxenham, M., Hoang, B.C., Dzung, N.K., Willis, A., Sarjeant, C., Piper, P., Matsumura, H., Tanaka, K., Beavan-Athfield, N., Higham, T., Nguyen, Q.M., Dang, N.K., Nguyen, K.T.K., Vo, T.H., Van, N.B., Tran, T.K.Q., Nguyen, P.T.,

Campos, F., Sato, Y.-I., Nguyen, L.C., Amano, N., 2011. An Son and the Neolithic of southern Vietnam. Asian Perspect. 50 (1), 144e175.

Blench, R., 2013. Was there once an arc of vegeculture linking Melanesia with Northeast India? In: Summerhayes, G.R., Buckley, H. (Eds.), Pacific Archaeology: Documenting the Past 50,000 Years to the Present, Studies in Prehistoric An- thropology, Vol. 25. University of Otago, Otago, pp. 1e16.

Bowman, A.R.A., 1966. Studies on the Heat Induced Carbonisation of Cereal Grains, Agricultural Botany. University of Reading, Reading.

Braadbaart, F., 2008. Carbonisation and morphological changes in modern dehusked and husked Triticum dicoccum and Triticum aestivum grains. Veg. Hist. Archaeobotany 17, $155 \mathrm{e} 166$.

Burkill, I.H., 1935. A Dictionary of the Economic Products of the Malay Peninsula. Published on behalf of the. Governments of Malaysia and Singapore by the Ministry of Agriculture and Co-operatives, Kuala Lumpur.

Castillo, C., 2011. Rice in Thailand: the archaeobotanical contribution. Rice 4, 114e120.

Castillo, C., 2013. The Archaeobotany of Khao Sam Kaeo and Phu Khao Thong: the Agriculture of Late Prehistoric Southern Thailand. Unpublished PhD disserta- tion. Institute of Archaeology, University College London. 
Castillo, C., in press. Development of cereal agriculture in prehistoric Mainland Southeast Asia. Man In India.

Castillo, C., Fuller, D.Q., 2010. Still too fragmentary and dependent upon chance? Advances in the study of early Southeast Asian archaeobotany. In: Bellina- Pryce, B., Pryce, T.O., Bacus, E., Wisseman-Christie, J. (Eds.), 50 Years of Archaeology in Southeast Asia: Essays in Honour of Ian Glover. River Books, Bangkok, pp. 90e111.

Castillo, C.C., Tanaka, K., Sato, Y.-I., Ishikawa, R., Bellina, B., Higham, C., Chang, N., Mohanty, R., Kajale, M., Fuller, D.Q., 2016a. Archaeogenetic study of prehistoric rice remains from Thailand and India: evidence of early japonica in South and Southeast Asia. Archaeol. Anthropol. Sci. 8 (3), 523e543.

Castillo, C., Bellina, B., Fuller, D.Q., 2016b. Rice, beans and trade crops on the early maritime silk route in Southeast Asia. Antiquity 90 (353), 1255e1269.

Colledge, S., 1994. Plant Exploitation on Epipalaeolithic And Early Neolithic Sites in the Levant. PhD dissertation. University of Sheffield.

Fuller, D.Q., unpublished. A Millet Atlas: Some Identification Criteria.

Fuller, D.Q., 2002. Fifty years of archaeobotanical studies in India: laying a solid foundation, in Indian archaeology in retrospect. Manohar. In: Settar, S., Korisettar, R. (Eds.), Archaeology and Interactive Disciplines, vol. III. Publications of the Indian Council for Historical Research, New Delhi, 247e364.

Fuller, D.Q., 2006. Agricultural origins and frontiers in South Asia: a working syn- thesis. J. World Prehistory 20, 1 e86.

Fuller, D.Q., Sato, Y.-I., Castillo, C., Qin, L., Weisskopf, A.R., Kingwell-Banham, E.J., Song, J., Ahn, S.-M., Etten, J.v, 2010. Consilience of genetics and archaeobotany in the entangled history of rice. Archaeol. Anthropol. Sci. 2, $115 \mathrm{e} 131$.

Galinato, M.I., Moody, K., Piggin, C.M., 1999. Upland rice Weeds of South and Southeast Asia. International Rice Research Institute, Makati City.

Glover, I.C., Higham, C.F.W., 1996. New evidence for early rice cultivation in South, Southeast and East Asia. In: Harris, D.R. (Ed.), The Origins and Spread of Agri- culture and Pastoralism in Eurasia. UCL Press, London, pp. $413 \mathrm{e} 441$.

Guedes, J.D.A., Butler, E.E., 2014. Modeling constraints on the spread of agriculture to Southwest China with thermal niche models. Quat. Int. 349, $29 \mathrm{e} 41$.

Harris, D.R., 1989. An evolutionary continuum of people-plant interaction. In: Harris, D.R., Hillman, G. (Eds.), Foraging and Farming: the Evolution of Plant Exploitation. Unwin Hyman Ltd., London, pp. $11 \mathrm{e} 26$.

Hather, J., 1991. The identification of charred archaeological remains of vegetative parenchymous tissue. J. Archaeol. Sci. 18, $661 \mathrm{e} 675$. 
Higham, C.F.W., 2013. Southeast Asian mainland: archaeology. In: Ness, I., Bellwood, P. (Eds.), The Encyclopedia of Global Human Migration, Vol. 1. Wiley- Blackwell, Hoboken, NJ, pp. 269e275.

Higham, C.F., Rispoli, F., 2014. The Mun Valley and Central Thailand in prehistory: integrating two cultural sequences. Open Archaeol. 1, 2e28.

Higham, C., Thosarat, R., 2004. Excavation of Khok Phanom Di. In: Volume 7: Summary and Conclusions. The Society of Antiquaries of London, London.

Higham, C., Thosarat, R., 2012. Early Thailand: from Prehistory to Sukhothai. River Books, Bangkok.

Higham, C.F.W., Guangmao, X., Qiang, L., 2011. The prehistory of a friction zone: first farmers and hunters-gatherers in Southeast Asia. Antiquity 85, 529e543.

Horie, T., Karahara, I., Katsuhara, M., 2012. Salinity tolerance mechanisms in gly- cophytes: an overview with the central focus on rice plants. Rice 5, 11. http:// dx.doi.org/10.1186/19398433-5-11.

Lakshminarasimhan, P., 1996. Monocotyledons. In: Sharma, B.D., Karthikeyan, S., Singh, N.P. (Eds.), Flora of Maharashtra State. Botanical Survey of India, Calcutta. Larson, G., Piperno, D.R., Allaby, R.G., Purugganan, M.D., Andersson, L., Arroyo- Kalin, M., Barton, L., Vigueira, C.C., Denham, T., Dobney, K., Doust, A.N., Gepts, P.,

Gilbert, M.T.P., Gremillion, K.J., Lucas, L., Lukens, L., Marshall, F.B., Olsen, K.M., Pires, J.C., Richerson, P.J., Rubio de Casas, R., Sanjur, O.I., Thomas, M.G., Fuller, D.Q., 2014. Current perspectives and the future of domestication studies. Proc. Natl. Acad. Sci. 111 (17), 6139e6146.

Lee, G.-A., Crawford, G.W., Liu, L., Chen, X., 2007. Plants and people from the early Neolithic to shang periods in north China. Proc. Natl. Acad. Sci. 104, 1087e1092. Liu, X., Hunt, H., Jones, M.K., 2009. River valleys and foothills: changing archaeo-

logical perceptions of North China's earliest farms. Antiquity 83, 82e95.

Lopez-Doriga, I.L., 2015. The Use of Plants during the Mesolithic and Neolithic in the Atlantic Coast of the Iberian Peninsula. PhD thesis. University of Cantabria.

Lu, T.L.D., 2002. A green foxtail (Setaria viridis) cultivation experiment in the Middle Yellow River Valley and some related issues. Asian Perspect. 41, 1e14.

Lu, T.L.D., 2009. Prehistoric coexistence: the expansion of farming society from the Yangzi river to western south China. In: Ikeya, K., Ogawa, H., Mitchell, P. (Eds.), Interactions between Hunteregatherers and Farmers: from Prehistory to Pre- sent. National Museum of Ethnology, Osaka, pp. 47e52.

Manguin, P.-Y., Vo, S.K., 2000. Excavations at the Ba The/Oc Eo complex (Viet Nam): a preliminary report on the 1998 campaign. In: Southeast Asian Archaeology 1998, pp. $107 \mathrm{e} 121$. 
Martin, A.C., Barkley, W.D., 2000. Seed Identification Manual. The Blackburn Press, New Jersey.

Matsumura, H., Oxenham, M.F., 2014. Demographic transitions and migration in Prehistoric East/Southeast Asia through the lens of nonmetric dental traits. Am.

J. Phys. Anthropol. 155, 45e65.

Moody, K., 1989. Weeds Reported in Rice in South and Southeast Asia. International Rice Research Institute, Los Ban os, Laguna.

Nasu, H., Momohara, A., Yasuda, Y., He, J., 2007. The occurrence and identification of Setaria italica (L.) P. Beauv. (foxtail millet) grains from the Chengtoushan site (ca. 5800 cal B.P.) in central China, with reference to the domestication centre in Asia. Veg. Hist. Archaeobotany 16 (6), 481e494.

Nguyen, D.T., 1970. Nature and human of the Hung Vuong period through pollen analysis at Trang Kenh site. Khao co hoc 7e8, 143 e144.

Nguyen, T.M.H., 2002. Flora vestiges at Dong Dau site through pollen analysis. Khao co hoc $1,60 \mathrm{e} 68$.

Nguyen, T.M.H., 2013. Neolithic vegetation in Northern Vietnam: an indication of early agricultural activities. J. Austron. Stud. 4 (1), $53 \mathrm{e} 73$.

Nguyen, V., 2008. Hoabinhian macrobotanical remains from archaeological sites in Vietnam: indicators of climate changes from the late Pleistocene to the early Holocene. Bull. Indo-Pac. Prehist. Assoc. 28, 80e83.

Nguyen, X.H., 1998. Rice remains from various archaeological sites in North and South Vietnam. In: Klokke, M.J., Bruijn, T.d. (Eds.), Southeast Asian Archaeology 1996. Centre for South-East Asian Studies, University of Hull, Hull, pp. 27e46.

Ohwi, J., 1965. Flora of Japan. Smithsonian Institution, Washington, D.C.

Oxenham, M.F., Buckley, H.R., 2016. The population history of mainland and island Southeast Asia. In: Oxenham, M.F., Buckley, H.R. (Eds.), The Routledge Hand- book of Bioarchaeology in Southeast Asia and the Pacific Islands. Routledge, London and New York, pp. $9 \mathrm{e} 23$.

Oxenham, M.F., Matsumura, H., 2016. Ban Non Wat as a test of the two-layer hy- pothesis. Am. J. Phys. Anthropol. 159 (2), 355e357.

Oxenham, M.F., Matsumura, H., Nguyen, K.D.D. (Eds.), 2011. Man Bac: the Excavation of a Neolithic Site in Northern Vietnam. The Biology. Terra Australis 33. Australian National University Press.

Oxenham, M.F., Piper, P., Bellwood, P., Bui, C.H., Nguyen, K.T.K., Nguyen, Q.M., Campos, F., Castillo, C., Wood, R., Sarjeant, C., Amano, N., Willis, A., Ceron, J., 2015. 
Emergence and diversification of the Neolithic in southern Vietnam: in- sights from Rach Nui. J. Isl. Coast. Archaeol. 10 (3), 309e338.

Pearsall, D.M., 1989. Paleoethnobotany: a Handbook of Procedures. Academic Press, San Diego.

Piper, P.J., Amano, N., 2013. A Preliminary Report on the Terrestrial Vertebrate Remains from Rach Nui, Long an Province, Vietnam (Unpublished report).

Piper, P.J., Oxenham, M.F., 2014. Of prehistoric pioneers: the establishment of the first sedentary settlements in the Mekong Delta region of southern Vietnam during the period 2000-1500 cal. BC. In: Boyle, K., Rabett, R., Hunt, C. (Eds.), Living in the Landscape: Essays in Honour of Graeme Barker, McDonald Insti- tute Monographs. McDonald Institute for Archaeological Research, Cambridge, pp. 209e226.

Piper, P.J., Campos, F., Ceron, J., Eusebio, M.S., Vuong, T.H., 2013. Preliminary Report on the mollusca recovered from the 2012 Excavations at Rach Nui (Long An Province, Southern Vietnam) (Unpublished report).

Piper, P.J., Campos, F.Z., Kinh, D.N., Amano, N., Oxenham, M., Hoang, B.C., Bellwood, P., Willis, A., 2014. Early evidence for pig and dog husbandry from the Neolithic site of an Son, Southern Vietnam. Int. J. Osteoarchaeol. $68 \mathrm{e} 78$.

Popper, V.S., Hastorf, C.A., 1988. Introduction. In: Hastorf, C.A., Popper, V.S. (Eds.), Current Paleoethnobotany: Analytical Methods and Cultural Interpretations of Archaeological Plant Remains. The University of Chicago Press, Chicago, pp. 1e16.

Price, T.D., 2000. Europe's first farmers: an introduction. In: Price, T.D. (Ed.), Europe's First Farmers. Cambridge University Press, Cambridge, pp. 1 e18.

Prior, R., 2000. Early Historic Ceramics from Tra Kieu, Central Vietnam: Typological and Petrographic Characterisation. PhD dissertation. University of London.

Rispoli, F., 2007. The incised and impressed pottery style of mainland Southeast Asia: following the paths of Neolithization. East West 57, $235 \mathrm{e} 304$.

Rohr, D.M., Boucot, A.J., Miller, J., Abbott, M., 1986. Oldest termite nest from the Upper Cretaceous of west Texas. Geology 14, 87e88.

Rozefelds, A.C., De Baar, M., 1991. Silicified Kalotermitidae (Isoptera) frass in conifer wood from a mid-Tertiary rainforest in central Queensland, Australia. Lethaia 24, 439e442.

Sarjeant, C., 2014. Contextualising the Neolithic Occupation of Southern Vietnam: the Role of Ceramics and Potters at An Son. Australian National University Press, Canberra.

Silva, F., Stevens, C.J., Weisskopf, A., Castillo, C., Qin, L., Bevan, A., Fuller, D.Q., 2015. Modelling the geographical origin of rice cultivation in Asia using the Rice Archaeological Database. PLOS one. http://dx.doi.org/10.1371/ journal.pone.0137024. 
Simpson, D.A., Inglis, C.A., 2001. Cyperaceae of economic, ethnobotanical and horticultural importance: a checklist. Kew Bull. 56 (2), 257, 360.

Simpson, D.A., Koyama, T., 1998. Flora of Thailand: Cyperaceae. In: Volume 6 Part 4.

The Forest Herbarium. Royal Forest Department, Bangkok.

Stevens, C.J., Fuller, D.Q., in press. The Spread of Agriculture in Eastern Asia: archaeological bases for hypothetical farmer/language dispersals. Lang. Dyn. Change.

Tan, M., Weisskopf, A., Fuller, D.Q., 2012. An Analysis of Phytolith Samples from an Son (Unpublished report).

Tanaka, Y., Nguyen, V.K., 2007. Edible Wild Plants of Vietnam. Orchid Press.

Thompson, G.B., 1996. The Excavation of Khok Phanom Di, a Prehistoric Site in Central Thailand. In: Vol. IV: Subsistence and Environment: the BotanicalEvidence (The Biological Remains, Part II). The Society of Antiquaries of London, London.

Thomson, M.J., de Ocampo, M., Egdane, J., Rahman, M.A., Sajise, A.G., Adorada, D.L., Tumimbang-Raiz, E., Blumwald, E., Seraj, Z.I., Singh, R.K., Gregorio, G.B., Ismail, A.M., 2010. Characterizing the Saltol quantitative trait locus for salinity tolerance in rice. Rice 3 (2e3), $148 \mathrm{e} 160$.

Tran, D.N., 1992. The florian at the Pleistocene-Holocene at Phong Chau, Vinh Phuc province. Khao co hoc 1, $29 \mathrm{e} 32$.

Tsang, C.H., 2005. Recent discoveries at the Tapengkeng sites. In: Sagart, L., Blench, R., Sanchez-Mazas, A. (Eds.), The Peopling of East Asia. Routledge Cur- zon, London, pp. $63 \mathrm{e} 74$.

Weisskopf, A., 2016. Elusive wild foods in South East Asian subsistence: modern ethnography and archaeological phytoliths. Quat. Int. 1e11.

Weber, S., Lehman, H., Barela, T., Hawks, S., Harriman, D., 2010. Rice or millets: early farming strategies in prehistoric central Thailand. Archaeol. Anthropol. Sci. 2, 79e88.

Wollstonecroft, M., Ellis, P.R., Hillman, G.C., Fuller, D.Q., 2008. Advancements in plant food processing in the Near Eastern Epipalaeolithic and implications for improved edibility and nutrient bioaccessibility: an experimental assessment of sea club-rush (Bolboschoenus maritimus (L.) Palla). Veg. Hist. Archaeobotany 17 (1), $19 \mathrm{e} 27$.

Wollstonecroft, M.M., Hroudova', Z., Hillman, G.C., Fuller, D.Q., 2011. Bolboschoenus glaucus (Lam.) SG Smith, a new species in the flora of the ancient Near East. Veg. Hist. Achaeobotany 20 (5), 459e470.

Woodrow, R.J., Grace, J.K., Yates, J.R., 1999. Hawaii's Termitesean Identification Guide. Cooperative Extension Service, College of Tropical Agriculture and Hu- man Resources. University of Hawaii at Manoa. 
Yang, X., Wan, Z., Perry, L., Lu, H., Wang, Q., Zhao, C., Li, J., Xie, F., Yu, J., Cui, T., Wang, T., Li, M., Ge, Q., 2012. Early millet use in northern China. Proc. Natl. Acad. Sci. $109,3726 \mathrm{e} 3730$.

Yang, X., Barton, H.J., Wan, Z., Li, Q., Ma, Z., Li, M., Zhang, D., Wei, J., 2013. Sago-type palms were an important plant food prior to rice in southern subtropical China. PloS one 8 (5), e63148.

Zeng, L., Shannon, M.C., 2000. Salinity effects on seedling growth and yield com- ponents of rice. Crop Sci. 40, 996e1003.

Zohary, D., Hopf, M., Weiss, E., 2012. Domestication of Plants in the Old World: the Origin and Spread of Domesticated Plants in South-west Asia, Europe, and the Mediterranean Basin, fourth ed. Oxford University.

Zvelebil, M., 1986. Hunters in Transition. Mesolithic Societies of Temperate Eurasia and Their Transition to Farming. Cambridge University Press.

On-line references

www.pfaf.org.

www.plantnet.rbgsyd.nsw.gov.au.

Figures 


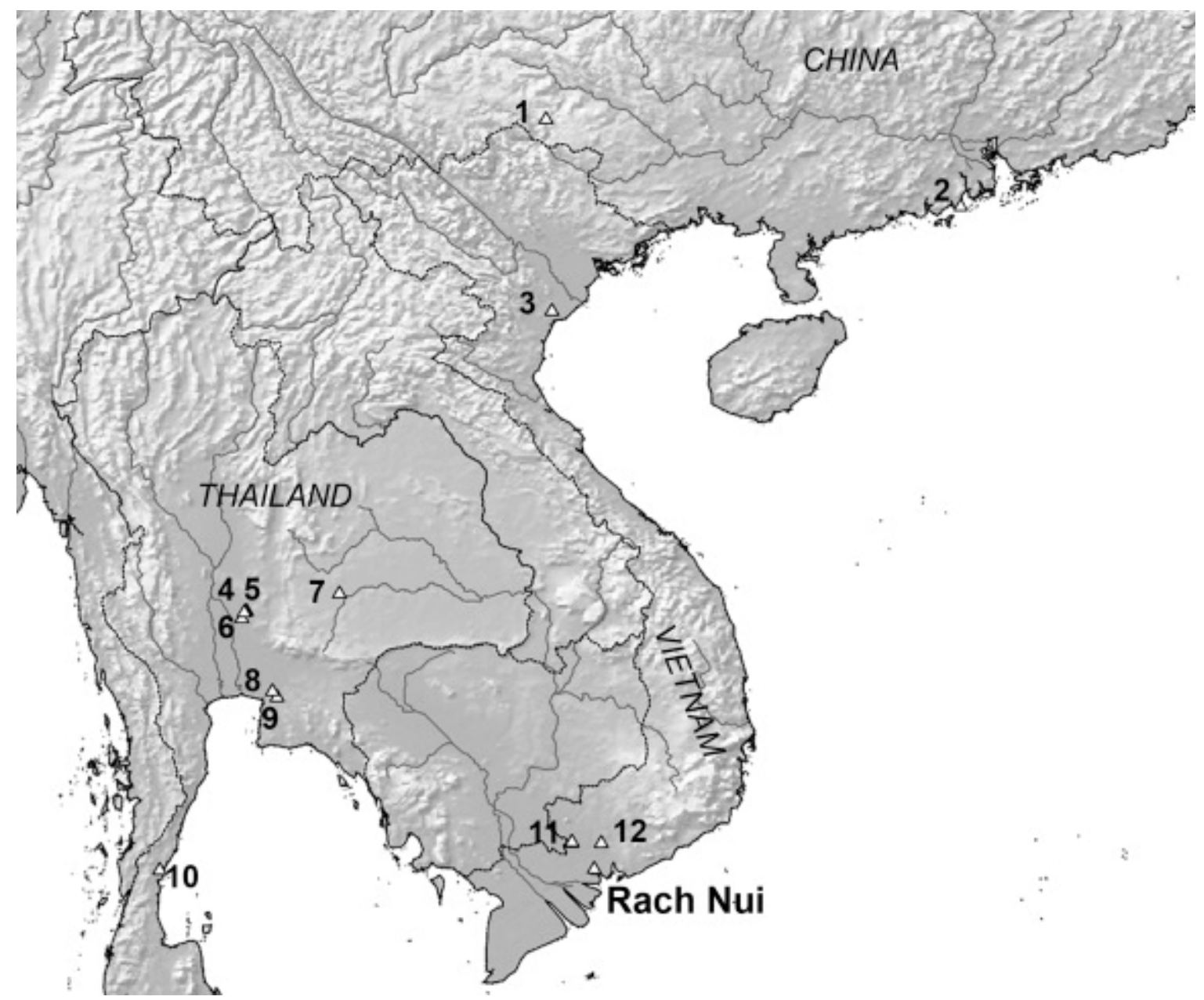

Fig. 1. Map showing the location of Rach Nui and other sites mentioned in the text: 1. Gantouyan; 2. Xincun; 3. Man Bac; 4. Nil Kham Haeng; 5. Non Pa Wai \& Non Mak La; 6. Tha Kae; 7. Ban Non Wat; 8. Khok Phanom Di; 9. Nong Nor; 10. Khao Sam Kaeo; 11. An Son \& Loc Giang; 12. Co Lao Rua (Map by D.Q. Fuller) 


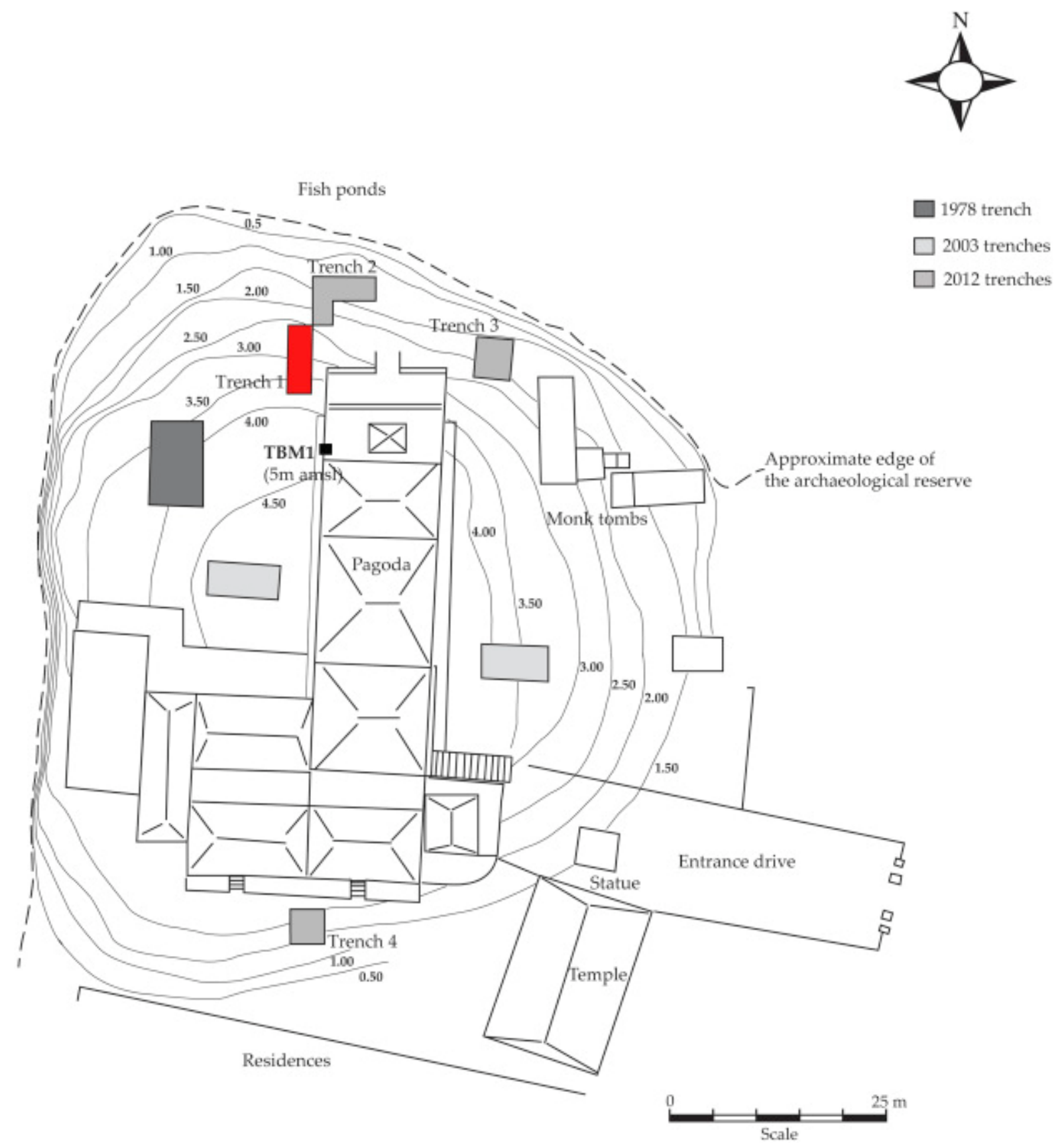

Fig. 2. Layout of the site showing the location of Trench 1 in red (Oxenham et al., 2015; Drawing by P. Piper).

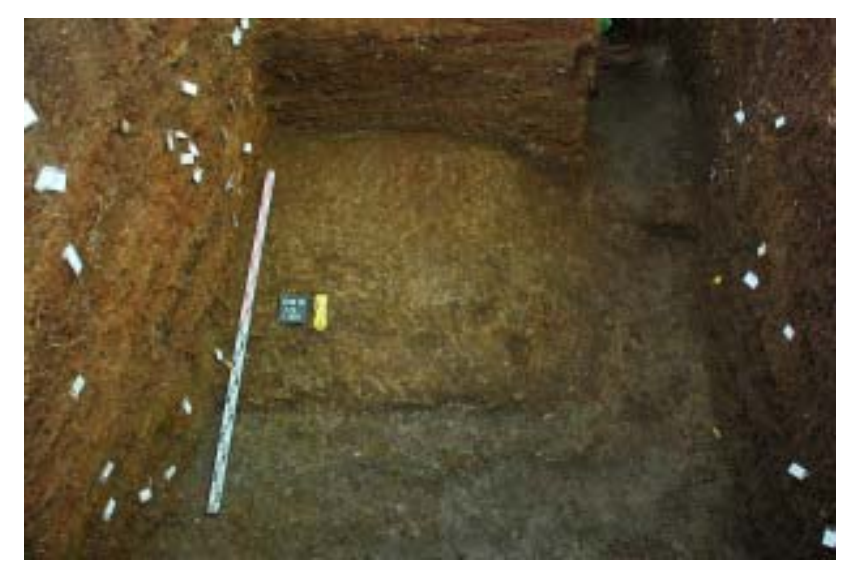

Fig. 3. Trench 1 showing a series of thin floor platforms (Image by Nguyễn Khánh Trung Kiên). 

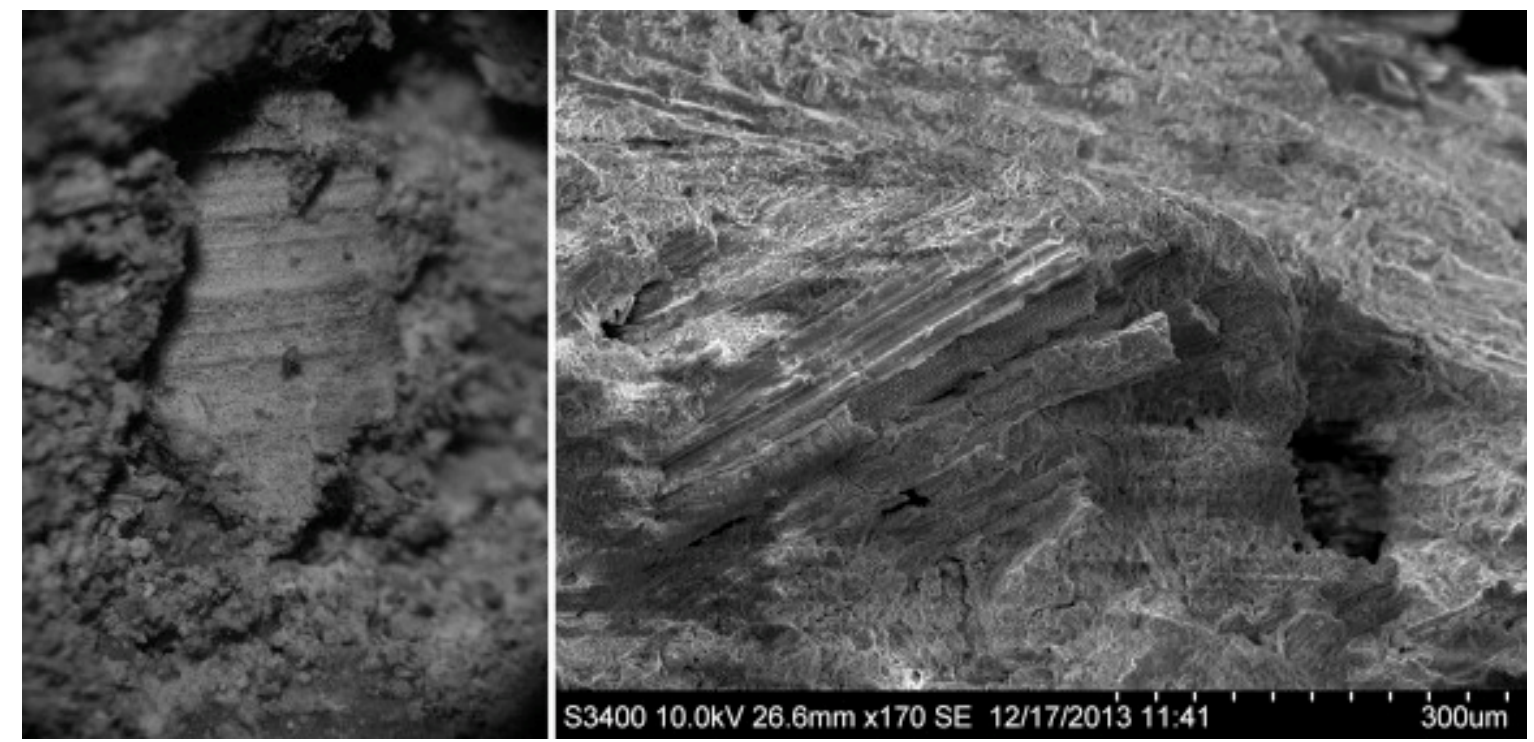

Fig. 4. Left- Silicified organic material on top portion of a platform in Rach Nui Trench 1; Right Scanning electron micrograph of a floor sample from Trench 1 showing charred wood remains (Images by C.C. Castillo)

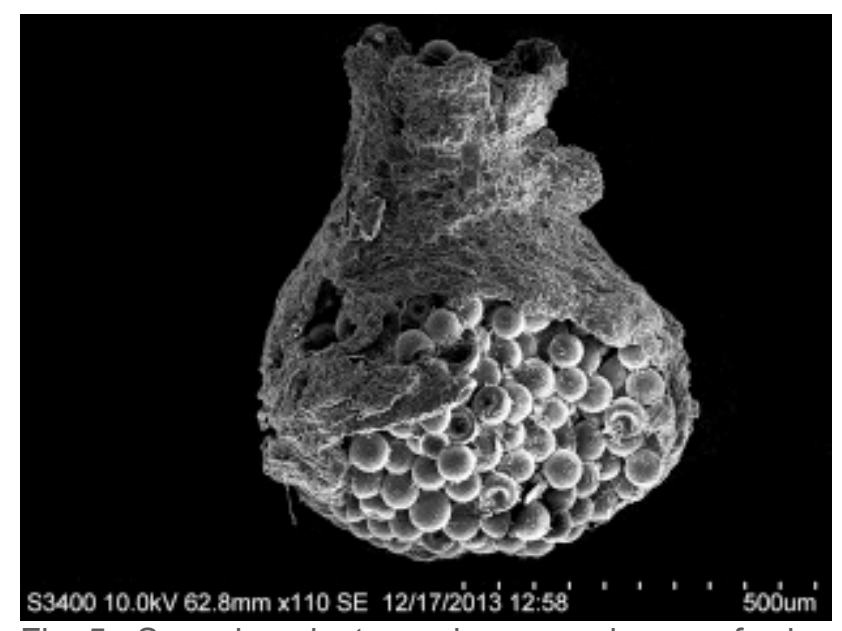

Fig. 5. Scanning electron microscopy image of sclerotium of a fungus in RN H1 F41/1 A1 (Images by C.C. Castillo)

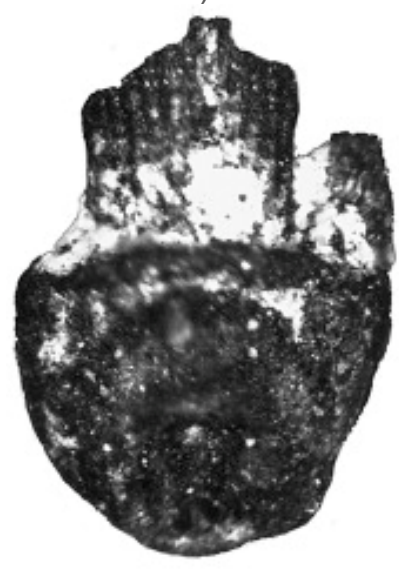

$0.5 \mathrm{~mm}$

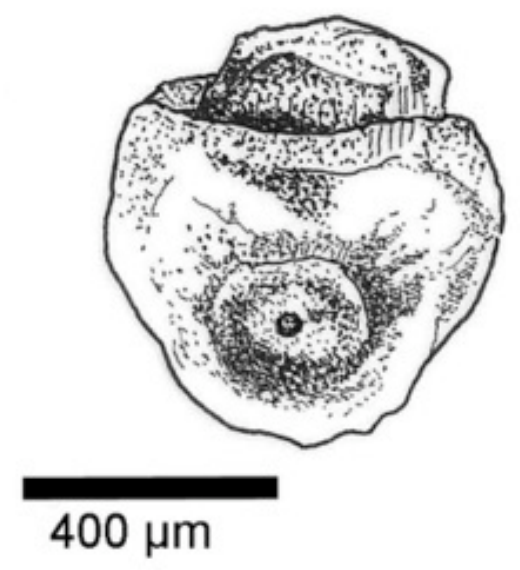

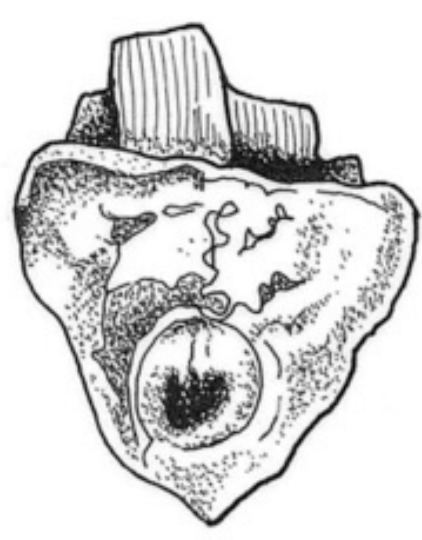

Fig. 6. Domesticated archaeological rice spikelet base from H1 L34/1 C3 1034/1 (Left), drawing of a domesticated (Centre) and a wild (Right) rice spikelet base (Image and drawings by C.C. Castillo). 


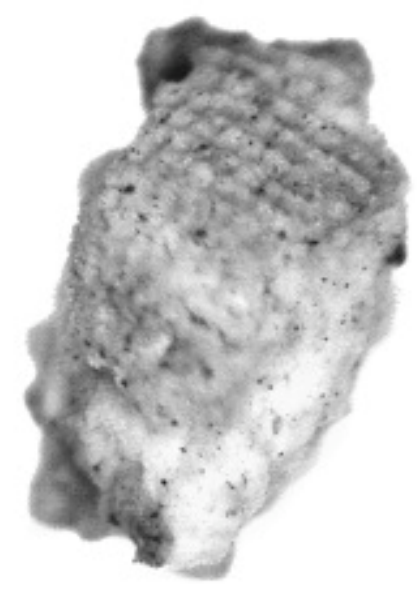

$0.5 \mathrm{~mm}$.

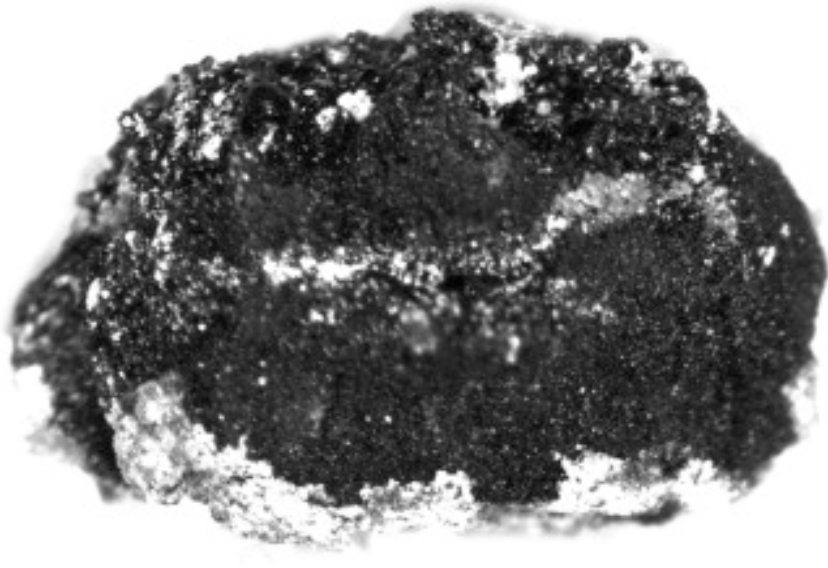

$1 \mathrm{~mm}$.

Fig. 7. Left: Silicified husk from RN H1 F42 A1; Right: Rice caryopsis from H1 L16/1 C3 (Images by C.C. Castillo).
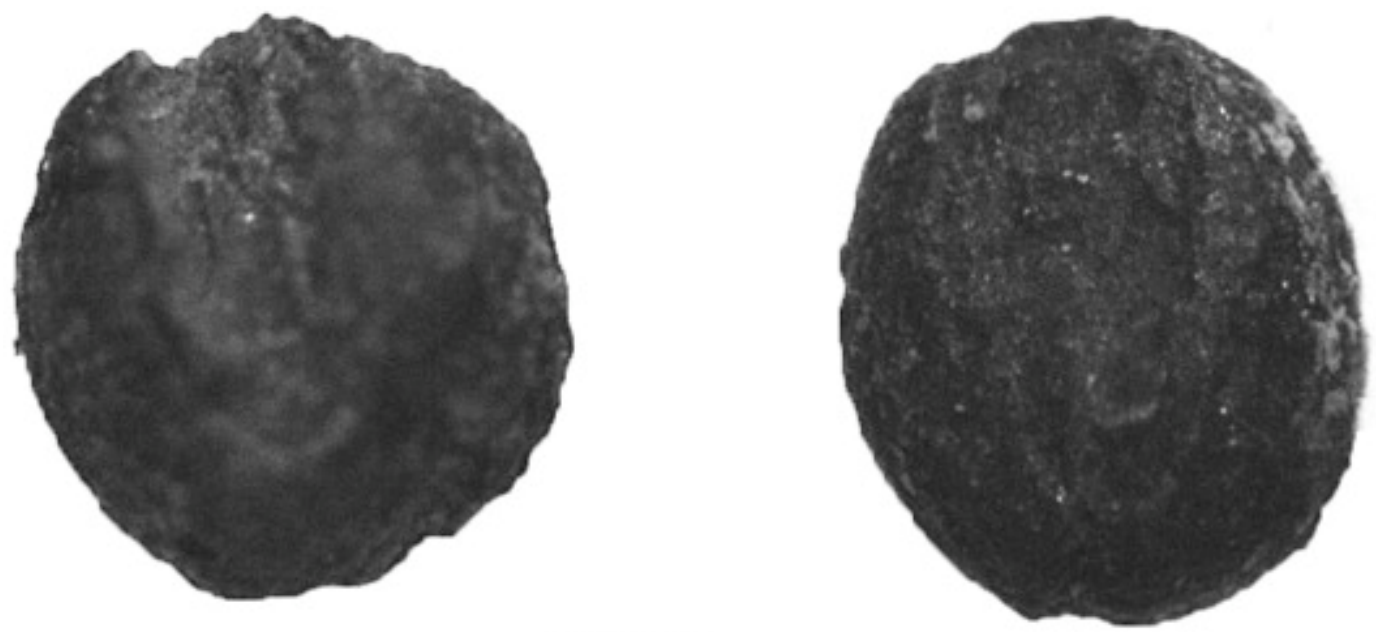

$0.5 \mathrm{~mm}$.

Fig. 8. Archaeological foxtail millet grains from Rach Nui showing the characteristic features of a plump and oval shape and long embryo (Images by C.C. Castillo) 


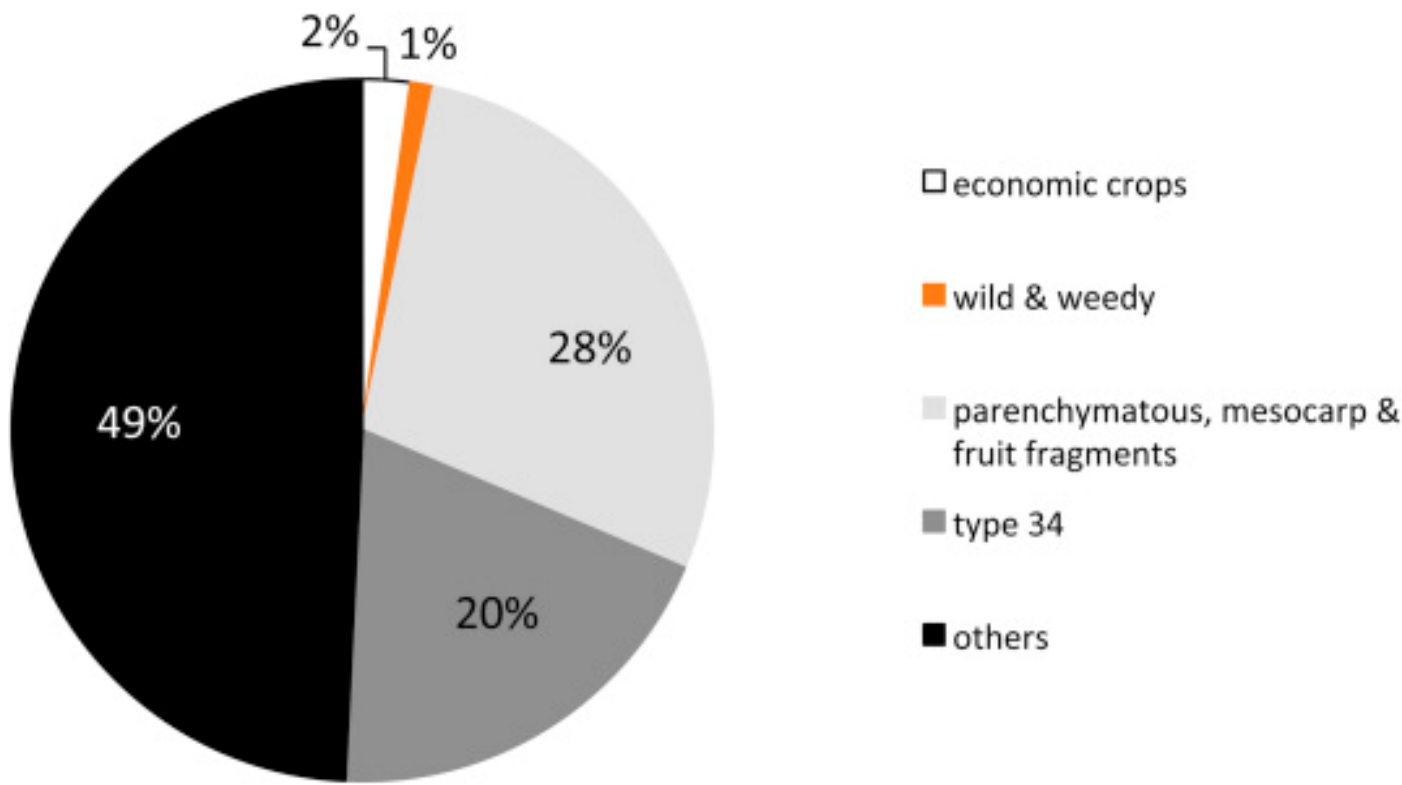

Fig. 9. Breakdown of plant remains into main groups represented in Trench 1. Parenchyma and mesocarp include fruit fragments.

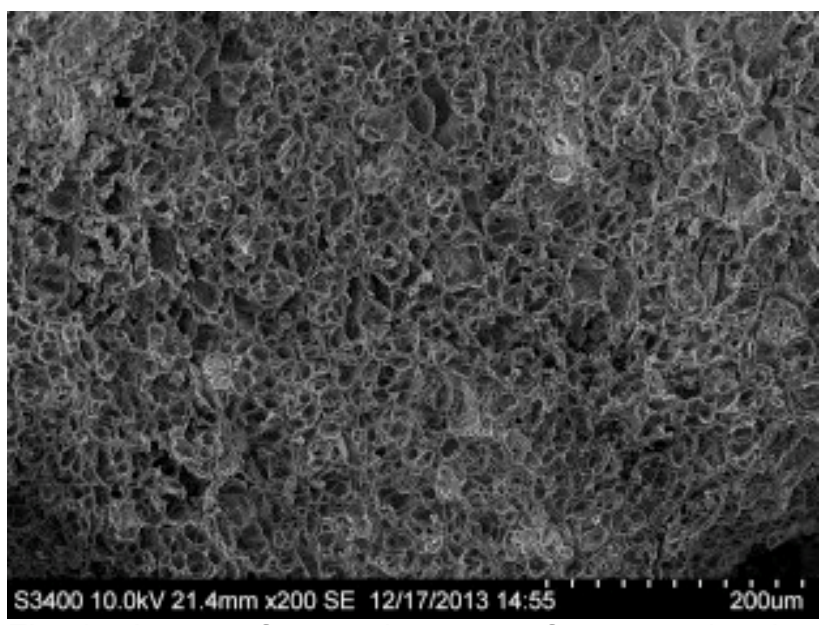

Fig. 10. Image of parenchymatous fragment showing distinctive spherical cells (H1 1034 A4) [Image by C.C. Castillo]

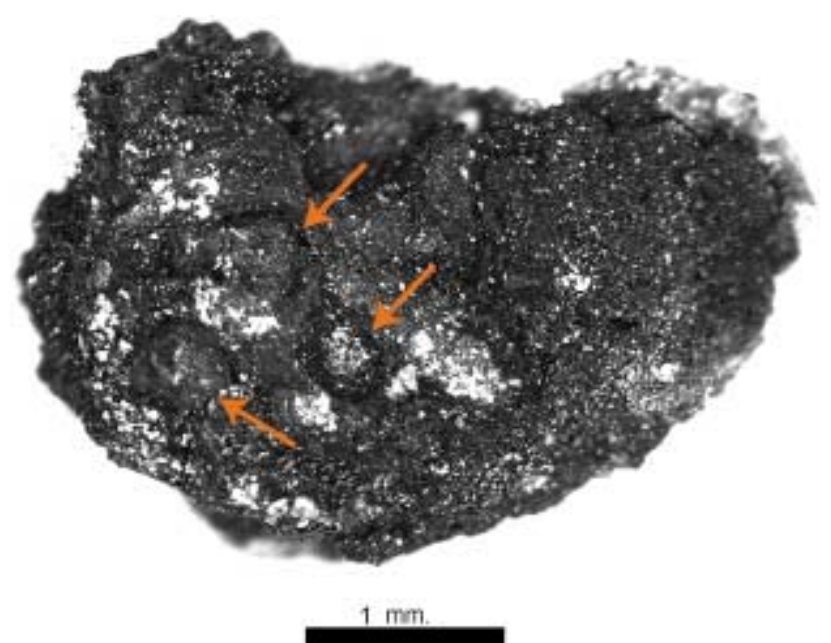

Fig. 11. Image of fruit fragment with arrows showing small seeds (H1 L16/1 C3) [Image by C.C. Castillo] 

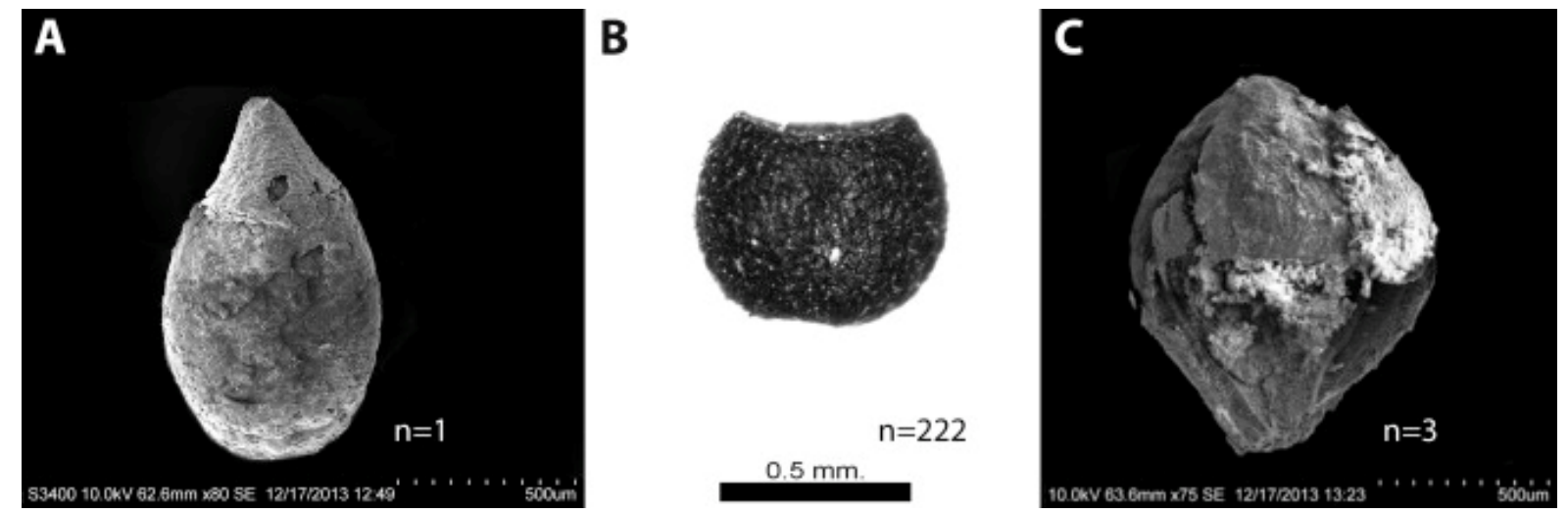

Fig. 12. Images of seeds classified as Scirpus sp. sensu lato from Rach Nui (A) cotyledon with the embryo still attached to it (H1 F2E/4 C8); (B) cotyledon or nutlet without pericarp or embryo (H1 L8 G/1); (C) nutlet with pericarp (H1 L18/1 A2 1018/1) [Images by C.C. Castillo].
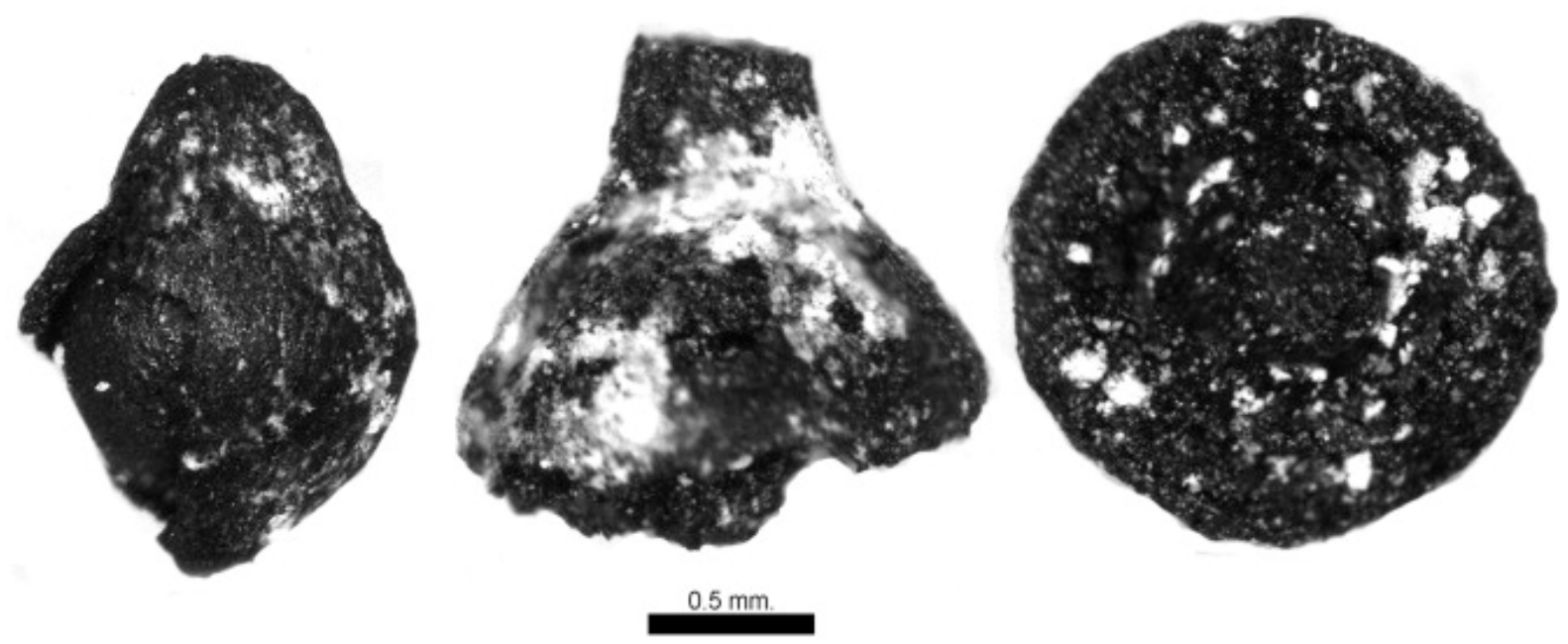

Fig. 13. Left: Image of seed classified as Scirpus sp. sensu lato. nutlet with fractured pericarp showing starchy endosperm (H1 F42 A1); Centre and right: Scirpus sp. rhizome detachment scar (H1 F2M A7) [Images by C.C. Castillo] 


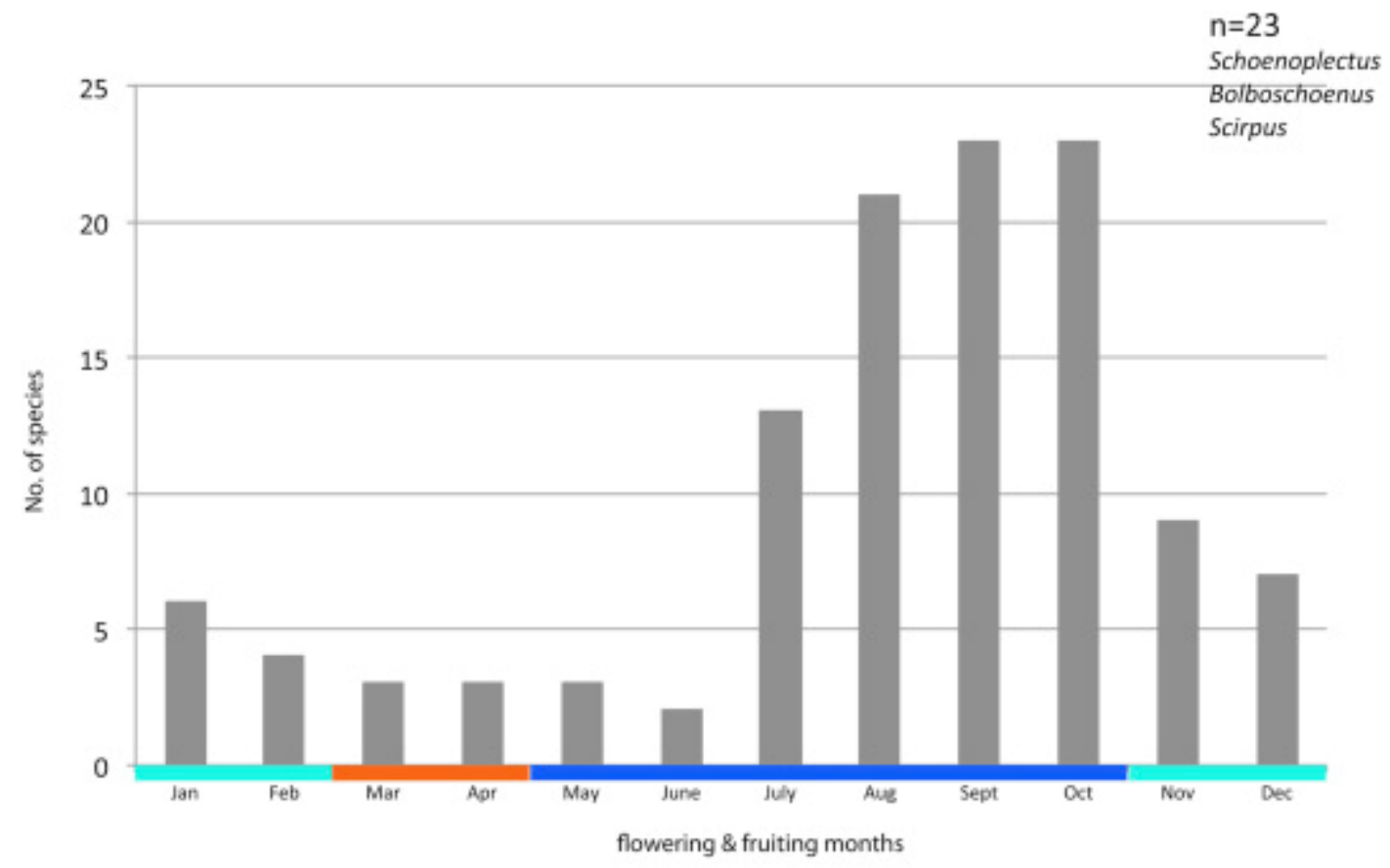

tuber gathering

tuber formation

Fig. 14. Graph showing the flowering, fruiting and tuber formation periods of sedges from the genera Schoenoplectus, Bolboschoenus and Scirpus in tropical Asia. The graph also shows the ideal period for tuber gathering. Light blue represents the winter season, orange is summer and dark blue is the wet season. (Source: Ohwi, 1965; Lakshminarasimhan, 1996).
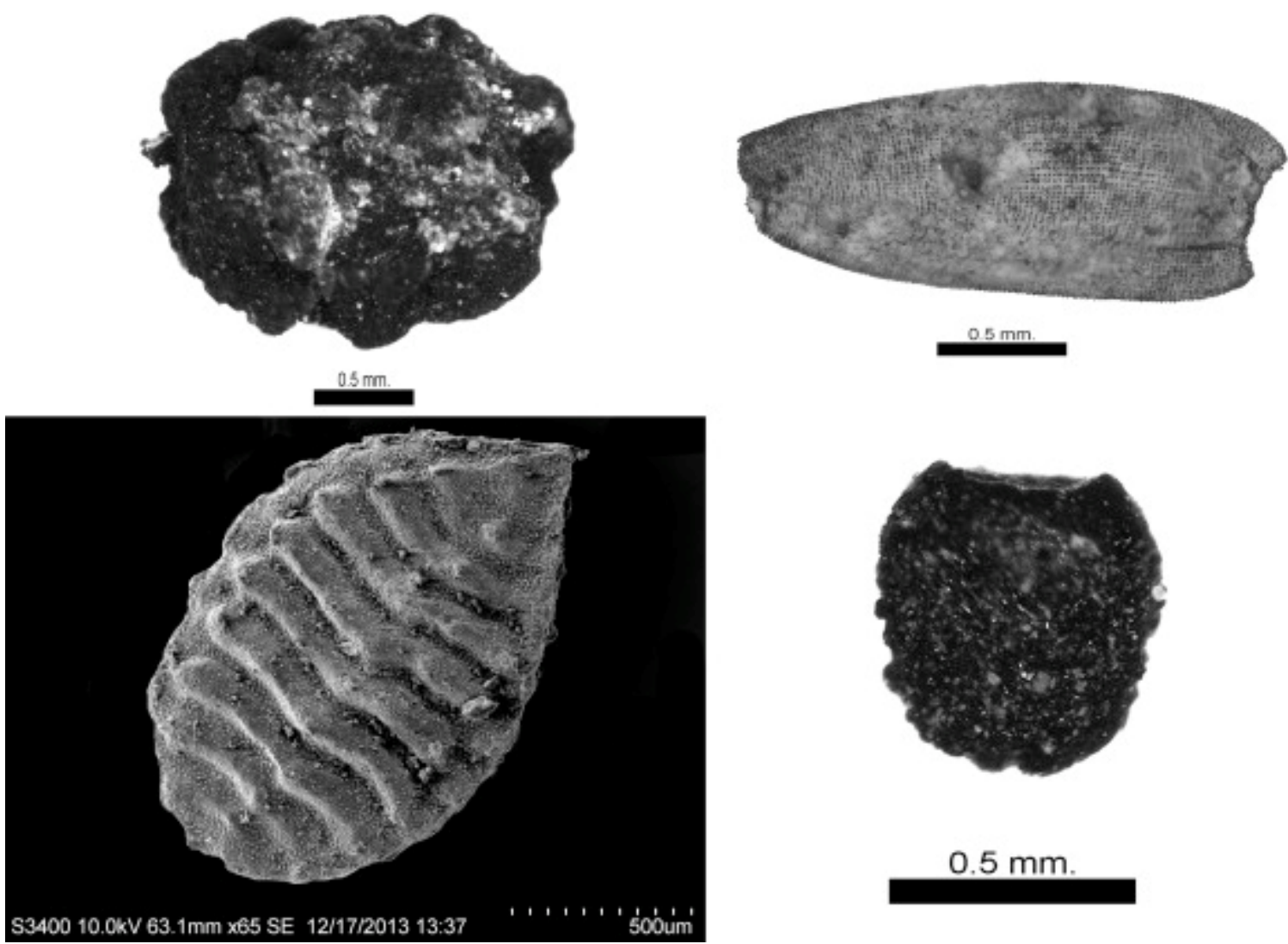

\section{$0.5 \mathrm{~mm}$.}

Fig. 15. Micrographs of weeds. Top left - Commelina benghalensis (H1 L18/1 A2 1018/1); Top right - Acmella paniculata (H1 L24/1 C4 1024/1); Lower left - Oxalis corniculata (H1 L17/1 A4 1017/1);

Lower right - Dactyloctenium cf. radulans (H1 F92/2 B6) [Images by C.C. Castillo]. 


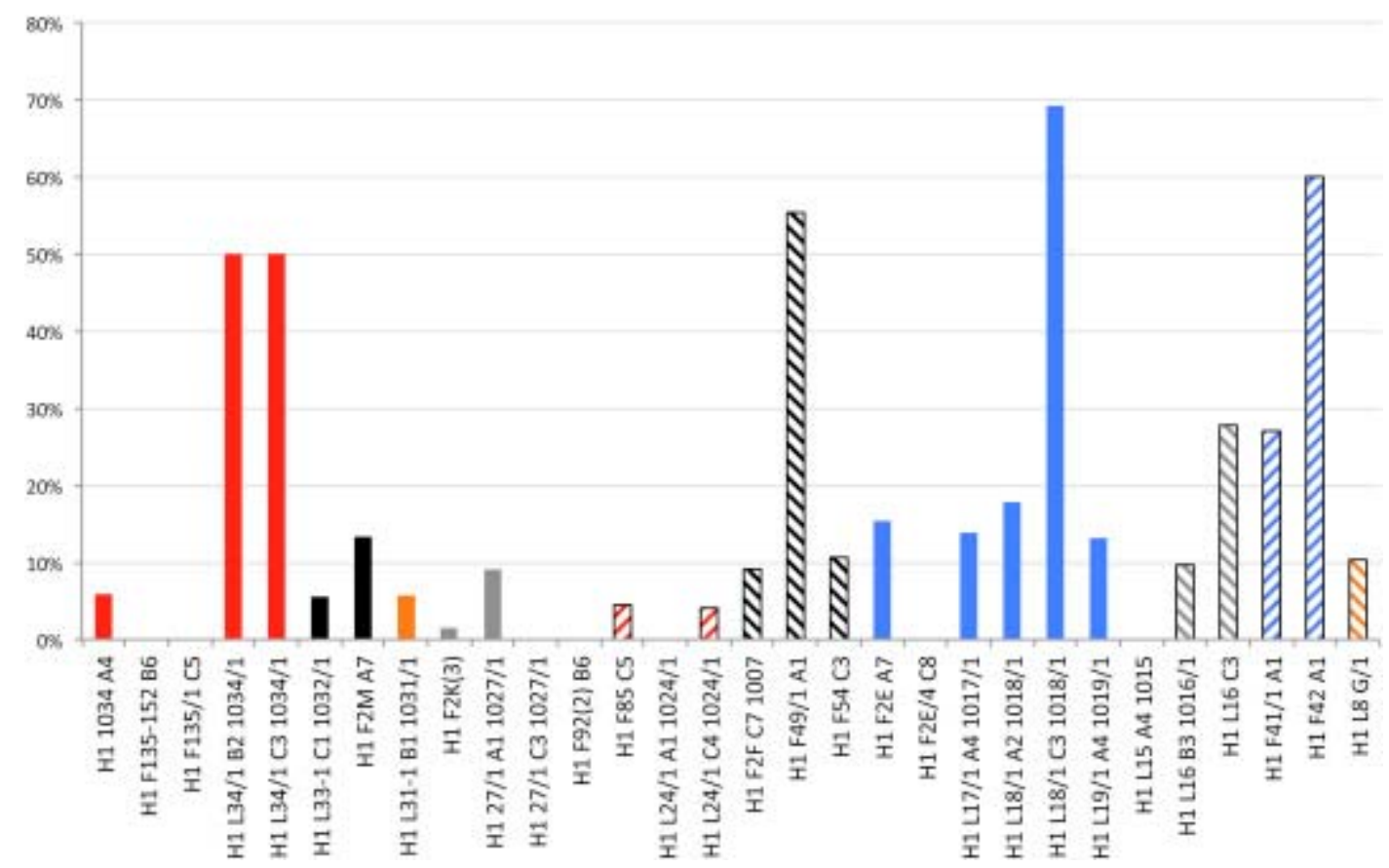

Fig. 16. Graph showing abundance of termite frass at Rach Nui Trench 1. Contexts arranged chronologically from left (earliest) to right (latest). The colours represent phases. (For interpretation of the references to colour in this figure legend, the reader is referred to the web version of this article.)

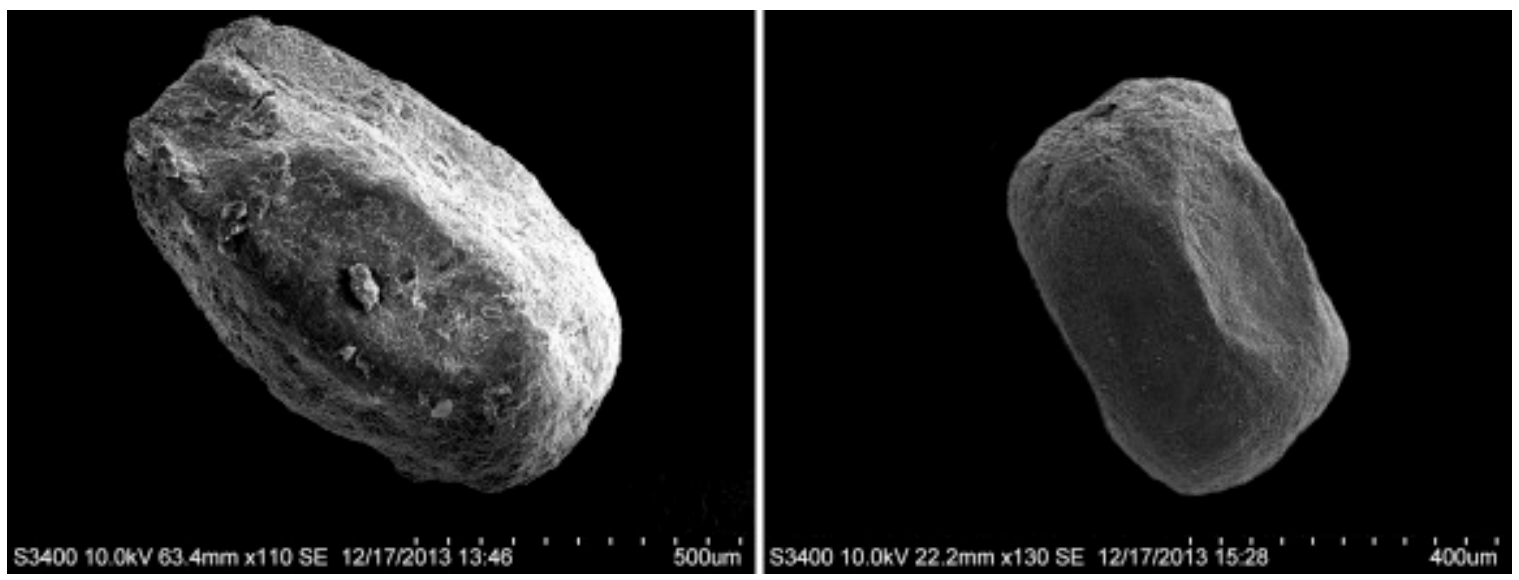

Fig. 17. Scanning electron micrographs of termite frass. Left - archaeological specimen from Rach Nui (H1 L34 C3 1034/1); Right - modern specimen from UP Los Baños (Images by C.C. Castillo).

\section{TABLES}

Table 1

Sites mentioned in the text, their corresponding cultural periods anddates.

\begin{tabular}{lll}
\hline Site name & Dates & Cultural period \\
\hline Gantouyan & $3500 \mathrm{e} 1000 \mathrm{BCE}$ & Late Neolithic - Bronze Age \\
Xincun & $3350 \mathrm{e} 2470 \mathrm{BCE}$ & Late Neolithic \\
Non Pa Wai & $2470 \mathrm{e} 700 \mathrm{BCE}$ & Neolithic - Iron Age \\
Tha Kae & $2200 \mathrm{e} 1700 \mathrm{BCE}$ & Neolithic \\
Man Bac & $2000 \mathrm{BCE}$ & Neolithic \\
An Son & $2100 \mathrm{e} 1050 \mathrm{BCE}$ & Neolithic \\
Non Mak La & $2100 \mathrm{e} 700 \mathrm{BCE}$ & Neolithic - Iron Age \\
Khok Phanom Di & $2000 \mathrm{e} 1400 \mathrm{BCE}$ & Neolithic \\
Loc Giang & $1800 \mathrm{e} 1400 \mathrm{BCE}$ & Neolithic \\
Ban Non Wat & $1650 \mathrm{BCEe} 500 \mathrm{AD}$ & Neolithic - Iron Age \\
Nil Kham Haeng & $1350 \mathrm{e} 500 \mathrm{BCE}$ & Neolithic - Iron Age \\
Nong Nor & $1100 \mathrm{e} 600 \mathrm{BCE}$ & Neolithic \\
Cu Lao Rua & $1500 \mathrm{e} 1000 \mathrm{BCE}$ & Late Neolithic - Early Bronze Age \\
Khao Sam Kaeo & $400 \mathrm{e} 100 \mathrm{BCE}$ & Metal age \\
\hline
\end{tabular}


Table 2

Vietnamese sites to have employed a methodology which resulted in plant remains.

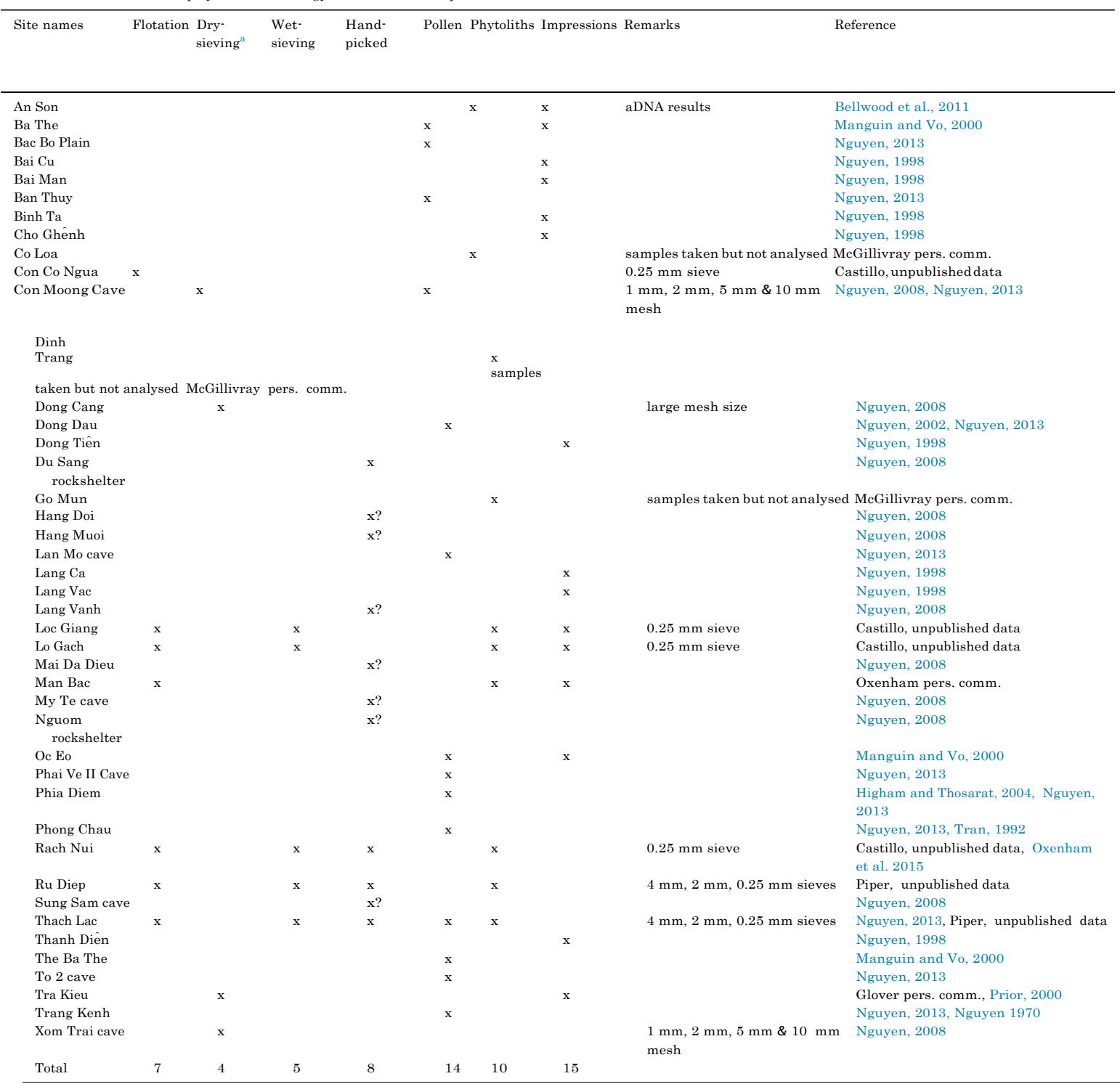

? Question marks are used to signify the uncertainty of the methodology used

as it is not mentioned in the references.

${ }^{a}$ Dry-sieving only reported if this method resulted in archaeobotanical remains retrieval.

Table 3

Summary statistics of the botanical datasets from flotation in Rach

Nui Trench 1.

\begin{tabular}{ll}
\hline No. of samples floated & 133 \\
Ave. volume of soil floated (1) & 8.13 \\
No. of samples sorted & 33 \\
NSP & 1735 \\
NISP & 1234 \\
Plant parts per litre MEAN & 4.11 \\
Plant parts per litre MIN & 0.12 \\
Plant parts per litre MAX & 17.33 \\
No. of taxa MODE & 1 \\
No. of taxa MIN & 0 \\
No. of taxa MAX & 4 \\
\hline
\end{tabular}


Table 4

Representation of all modern seeds and fungal sclerotia found in Trench 1. The highlighted samples potentially have high levels of bioturbation. Contexts are arranged chronologically from latest to earliest.

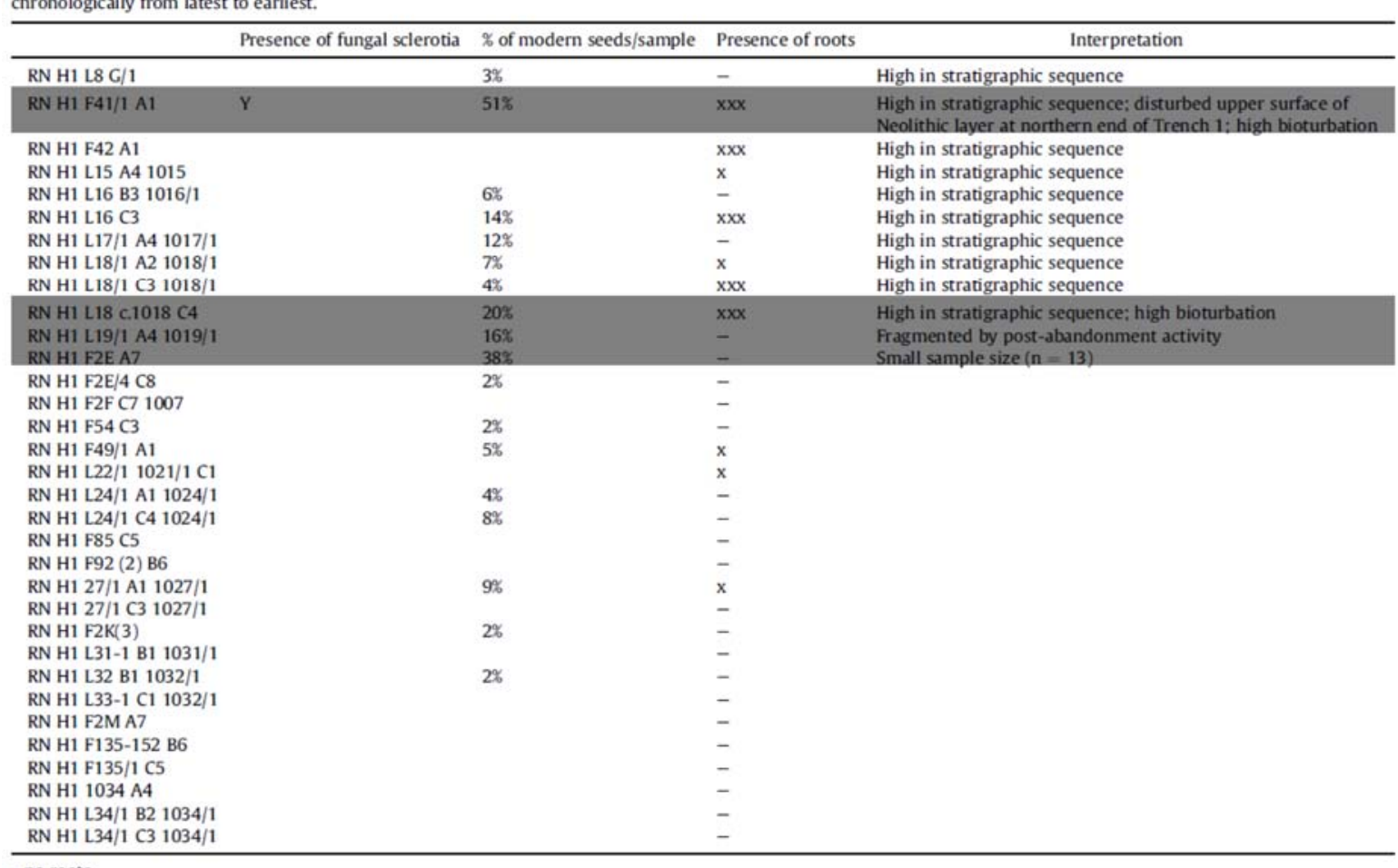

- no roots.

$x$ a few roots, $25 \%$ or less

$x x$ many roots, $>25-60 \%$ of sample is made up of roots.

$x x x$ mostly roots, $>60 \%$ of sample is made up of roots.

Table 5

List of cereals and the weeds found in Rach Nui. Samples where no cereals or weeds were found are omitted from the table. Highlighted are the samples containing economic crops and weeds in the same context. NSP refers to unspecified habitats. Contexts are arranged chronologically from latest to earliest

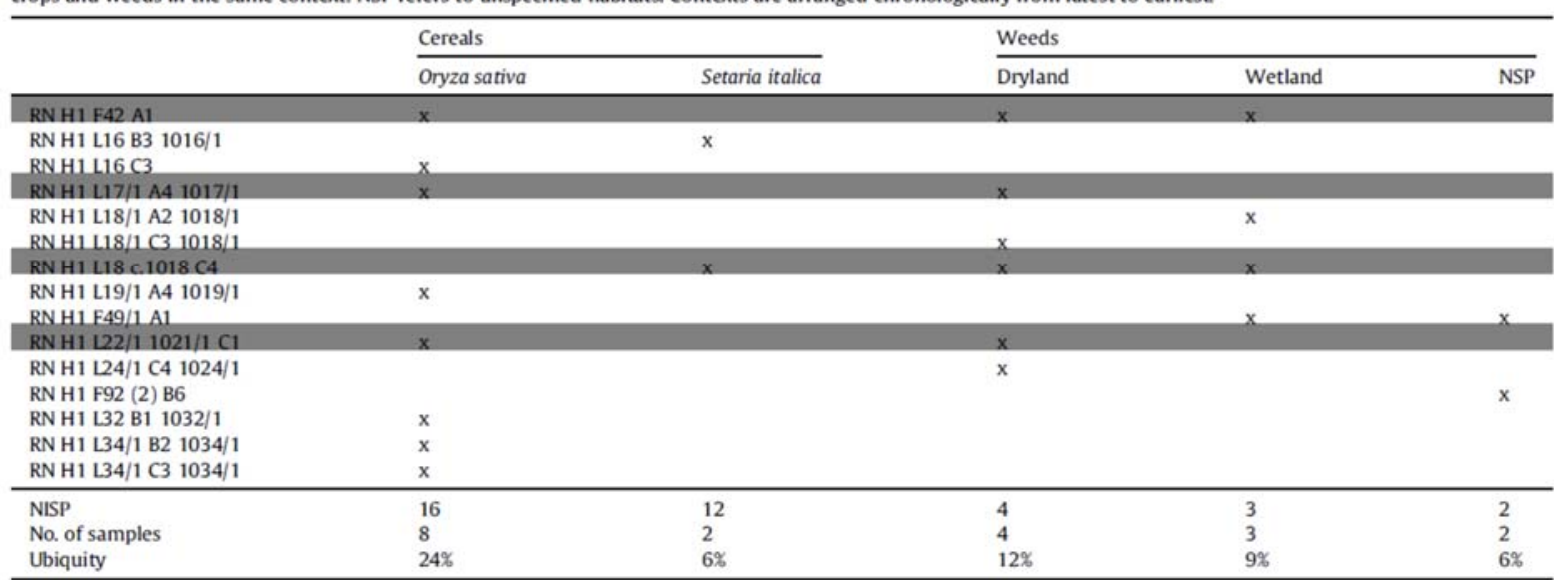

Table 6

Measurements of the archaeological Setaria italica from Rach Nui ( $\mathrm{n}^{1 / 4}$

$\underline{6)}$.

\begin{tabular}{llllll}
\hline & Length $(\mathrm{mm})$ & Width $(\mathrm{mm})$ & Thickness $(\mathrm{mm})$ & Embryo length $(\mathrm{mm})$ & Embryo length ratio \\
\hline Mean & 1.05 & 1.00 & 0.70 & 0.76 & $75.31 \%$ \\
Median & 1.06 & 0.95 & 0.73 & 0.75 & $76.33 \%$ \\
Minimum & 0.91 & 0.87 & 0.57 & 0.64 & $68.97 \%$ \\
Maximum & 1.19 & 0.76 & 0.90 & $79.60 \%$ \\
\hline
\end{tabular}


Table 7

Measurements of archaeological and modern foxtail millet.

\begin{tabular}{llll}
\hline & Length $(\mathrm{mm})$ & Width $(\mathrm{mm})$ & Thickness \\
\hline (mm) Rach Nui (n 1/4 6) & 1.05 & 1.00 & 0.70 \\
Khao Sam Kaeo (n 1/4 1) & 0.90 & 0.90 & \\
Modern1 & 2.00 & 2.00 & \\
Modern2 & $1.9 \mathrm{e} 2.5$ & $1.4 \mathrm{e} 1.9$ & $1.1 \mathrm{e} 1.7$ \\
Modern3 & $1.51 \mathrm{e} 2.52$ & $1.32 \mathrm{e} 2.14$ & $1 \mathrm{e} 1.9$ \\
Modern4 & $1.4 \mathrm{e} 1.9$ & $1.1 \mathrm{e} 1.8$ & $0.7 \mathrm{e} 1.5$ \\
Modern5 & $1.08 \mathrm{e} 2.2$ & $1.26 \mathrm{e} 1.83$ & $0.92 \mathrm{e} 1.52$ \\
Modern6 & $2.2 \mathrm{e} 2.8$ & $1.2 \mathrm{e} 1.7$ & $1 \mathrm{e} 1.15$ \\
Modern7 & $1.4 \mathrm{e} 1.72$ & $1.45 \mathrm{e} 1.92$ & $0.93 \mathrm{e} 1.36$ \\
\hline
\end{tabular}

Modern1 - fresh samples, Digital Atlas of Economic Plant

Modern2 - fresh samples, IoA reference collection husked, from China, $n$ 1/4 190

Modern3 - carbonised samples, IoA reference collection husked, from China, $n$ 1/4 51 .

Modern 4 - fresh samples, IoA reference collection dehusked, from China, n 1/4 190

Modern5 - carbonised samples, IoA reference collection dehusked, from China,

n $1 / 49$.

Modern6 - fresh samples, IoA reference collection dehusked, from India, n $1 / 4170$

Modern 7 - carbonised samples, IoA reference collection dehusked, from India, $n^{1 / 4} 4$

Table 8

Weeds found in Trench 1, their Vietnamese names and the type of cultivatio system they are most likely found in.

\begin{tabular}{|c|c|c|c|}
\hline Family & Species & Vietnamese name & Remarks \\
\hline Asteraceae & Acmella paniculata & Cúc ao hoa vang, cúc ao, kim hoa & $\begin{array}{l}\text { Spilanthes paniculata is a synonym; weed also reported in shifting cultivation; } \\
\text { grows in upland and rainfed fields. }\end{array}$ \\
\hline Commelinaceae & Commelina benghalensis & & Reported as a weed of rice in Vietnam; upland weed \\
\hline Oxalidaceae & Oxalis corniculata & Me dât nhỏ & Reported as a weed of rice in Vietnam; upland and transplanted fields \\
\hline
\end{tabular}

References: Galinato et al., 1999; Moody 1989; www.pfaf.org;

www.plantnet.rbgsyd.nsw.gov.au; Tanaka and Nguyen 2007. 